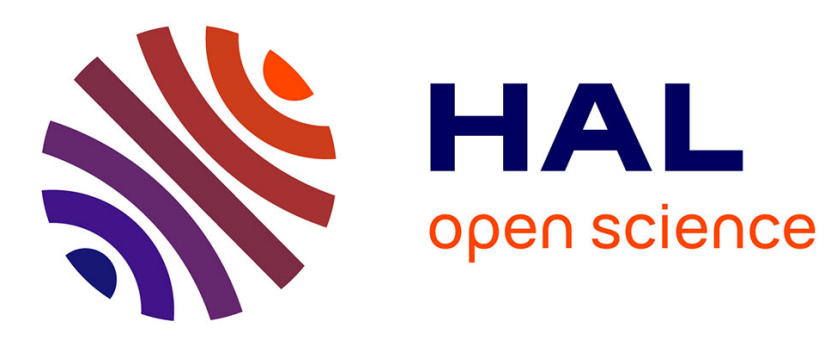

\title{
Deformation of basaltic shield volcanoes under cointrusive stress permutations
}

Marie Chaput, Vincent Famin, Laurent Michon

\section{To cite this version:}

Marie Chaput, Vincent Famin, Laurent Michon. Deformation of basaltic shield volcanoes under cointrusive stress permutations. Journal of Geophysical Research: Solid Earth, 2014, 119 (1), pp.274301. 10.1002/2013JB010623 . hal-01147426

\section{HAL Id: hal-01147426 https://hal.science/hal-01147426}

Submitted on 14 Dec 2015

HAL is a multi-disciplinary open access archive for the deposit and dissemination of scientific research documents, whether they are published or not. The documents may come from teaching and research institutions in France or abroad, or from public or private research centers.
L'archive ouverte pluridisciplinaire HAL, est destinée au dépôt et à la diffusion de documents scientifiques de niveau recherche, publiés ou non, émanant des établissements d'enseignement et de recherche français ou étrangers, des laboratoires publics ou privés. 


\section{Journal of Geophysical Research: Solid Earth}

\section{RESEARCH ARTICLE Deformation of basaltic shield volcanoes \\ 10.1002/2013JB010623 under cointrusive stress permutations}

Key Points:

- Perpendicular intrusions and stress fields control deformation at La Reunion

- A model of cyclic stress permutations related to magma intrusions is proposed

- Stress permutations and sill zone are consequences of insufficient volcano creep

\section{Correspondence to:}

M. Chaput,

marie.chaput@univ-reunion.fr

\section{Citation:}

Chaput, M., V. Famin, and L. Michon (2014), Deformation of basaltic shield volcanoes under cointrusive stress permutations, J. Geophys. Res. Solid Earth, 119, 274-301, doi:10.1002/2013JB010623.

Received 21 AUG 2013 Accepted 13 DEC 2013 Accepted article online 2 JAN 2014 Published online 29 JAN 2014

\author{
Marie Chaput ${ }^{1}$, Vincent Famin ${ }^{1}$, and Laurent Michon ${ }^{1}$ \\ 'Laboratoire GéoSciences Réunion, Université de la Réunion, Institut de Physique du Globe de Paris, Saint-Denis, France
}

\begin{abstract}
We performed a microstructural study of Piton des Neiges (La Réunion Island) to understand how intrusions and stresses control each other in basaltic volcanoes. Our study reveals that three perpendicular intrusions trends coexisted during the $2 \mathrm{Myr}$ history of the volcano: a N120-140 $\mathrm{E}$ rift zone, a perpendicular dike trend, and swarms of subhorizontal intrusions hereafter called "sill zones". Independently, the inversion of fault-slip data shows that incompatible paleostress fields recurrently occurred along with the intrusions: a dominant NNE-SSW extension, a perpendicular extension, and strike-slip or compressional regimes. The orientations of paleostresses are consistent with the orientations of the three perpendicular intrusion populations. We propose that stress accumulation in the edifice under the effect of repeated magma injections resulted in permutations of the principal axes of the stress tensor, causing a reorientation of subsequent intrusions. Stress permutations were cyclical. Each cycle started with dike injections in an extensional stress field, reducing the deviatoric stress and switching the axes of principal stresses, and finished with sill intrusions in a compressional stress field. Sill zones acted as detachment planes, restoring the extensional stress field and initiating a new cycle of permutations. Our model of stress permutations is in agreement with the pattern of eruptions and deformation observed at Piton de la Fournaise. In contrast with the Hawaiian model of spreading on a décollement, stress permutations in La Réunion's volcanoes imply that the basal deformation of the edifices, if any, is not sufficient to compensate the reduction of deviatoric stress caused by intrusions.
\end{abstract}

\section{Introduction}

We address the question of how deformation proceeds in basaltic volcanoes. In the absence of regional tectonics, the main force governing volcano deformation is the gravitational stress. Two end-member models of gravity-driven deformation have been proposed: sagging and spreading [Zucca et al., 1982; Borgia, 1994; Merle and Borgia, 1996; van Wyk de Vries and Borgia, 1996; van Wyk de Vries and Matela, 1998]. The sagging model explains volcano deformation by lithospheric flexure under the weight of the edifice and is dominated by compressional structures such as thrusts and flank terraces [Byrne et al., 2013]. In the spreading model, gravitational deformation is achieved by a décollement (associated with folds and thrusts) at the base of the edifice and by extension on the flanks (with normal faults and "leaf grabens" [Oehler et al., 2005; Byrne et al., 2013]). In addition to gravity, several other forces may also drive the deformation of basaltic shields, such as magma chamber pressurization [e.g., Gudmundsson, 2006] or magma intrusions [Swanson et al., 1976; McGuire, 1996; Walker, 1999]. Deformation is also dependent on the rheology of the edifice and may be influenced by hydrothermal alteration [López and Williams, 1993; Cecchi et al., 2005], weak internal horizons [Oehler et al., 2005; Famin and Michon, 2010], or creeping cumulates [Clague and Denlinger, 1994].

Most volcanoes exhibit a mixed deformation behavior. This is the case at Kilauea and Mauna Loa (Hawaii), where a lithospheric flexure, a basal décollement [e.g., Denlinger and Okubo, 1995; Owen et al., 1995], repeated injection of dikes in rift zones [e.g., Swanson et al., 1976; Dieterich, 1988], and weakening processes all participate in the deformation of the edifices. In particular, the synchronous occurrence of slip events on the basal décollement and magma injections in rift zones observed at Kilauea suggests a relationship between spreading and magmatic activity [Owen et al., 2000; Brooks et al., 2008; Montgomery-Brown et al., 2011]. However, other deformed volcanoes remain problematic because they lack some important characteristic features of the above models. For instance, a prominent lithospheric flexure is evidenced under Tenerife (Canary Islands) [Collier and Watts, 2001], but the compressional structures typical of sagging are not observed and rifting dominates on the flanks [e.g., Galindo et al., 2005; Geyer and Martì, 2010]. At La Palma, the 
long-lasting extension [Day et al., 1999; Fernández et al., 2002; González et al., 2010] would be consistent with spreading, but there is no evidence of an active basal décollement [Carracedo, 1999; Mitchell et al., 2002]. Piton de la Fournaise (La Réunion Island) is perhaps the most striking example of this problematic category: Despite an important active subaerial deformation and eruptive activity, the notorious lack of lithospheric flexure, the absence of a décollement or even of basal compression [de Voogd et al., 1999; Le Friant et al., 2011], and the tenuous rift zones do not match any of the aforementioned models. For Piton de la Fournaise and other basaltic volcanoes alike, the structures accommodating deformation remain debated, as do the driving forces of deformation.

Additional information about the mechanisms of volcano deformation can be provided by direct observation of the inner structure of extinct eroded volcanoes. On La Gomera and La Palma volcanoes (Canary Islands), thick swarms of low-dipping intrusions are observed, often in association with deformation structures [Staudigel et al., 1986; Fernández et al., 2002; Ancochea et al., 2008]. A recent study on Piton des Neiges volcano (La Réunion Island) also reported the exposure of an outward detachment (i.e., a low-angle normal fault) intruded by a thick pile of basic magma injections. Famin and Michon [2010] proposed that these lowdipping intrusions in the detachment contributed to the long-term destabilization of the edifice by both cointrusive rapid slip and interintrusive slow deformation. These examples suggest that magma injections and internal deformation may be coupled through a different process than that in the spreading and rift zones model.

This paper is an extension of Famin and Michon [2010], designed to provide a mechanical framework for the deformation of basaltic volcanoes that do not show obvious evidence of spreading on a basal décollement. We explored how deformation can be related to low-dipping intrusions, taking Piton des Neiges as the case study because of its exceptional exposure conditions (Figure 1). To do so, we performed a detailed reinvestigation of the geometrical features of intrusions and of the deformation structures that have affected the edifice during its evolution. We applied an inversion procedure to the intrusion and fault-slip data to reconstruct the stress field under which magma injections and deformation were generated. Our results reveal a strong mechanical feedback between intrusions geometries, stress orientations, and volcano deformation. These new constraints allow us to propose an alternative model for the relationship between deformation and magmatic activity in basaltic volcanoes.

\section{Geological Setting}

La Réunion is an $~ 5$ Myr old basaltic edifice, built on the oceanic crust at $4000 \mathrm{~m}$ below sea level, and displaying a subcircular shape $200-240 \mathrm{~km}$ in diameter (Figure 1). The subaerial part of La Réunion is made of two main volcanoes, Piton des Neiges (inactive) to the west and Piton de la Fournaise (active) to the east. Piton des Neiges volcano began its shield-building stage (i.e., emersion and rapid growth) before $2.2 \mathrm{Myr}$ and produced exclusively transitional basic magmas until 430 kyr [McDougall, 1971; Kluska, 1997]. The degenerative stage (i.e., explosive activity and progressive extinction) occurred from $350 \mathrm{kyr}$ to $29 \mathrm{kyr}$ [Gillot and Nativel, 1982; Kluska, 1997], with the emission of alkalic differentiated magmas. Piton des Neiges is incised by three cirques (subcircular depressions): Salazie to the north, Mafate to the northwest, and Cilaos to the south. These depressions have been alternatively interpreted as scars of large destabilizations during the shield-building stage [Bret et al., 2003; Oehler et al., 2004, 2007], as "leaf grabens" caused by gravitational spreading [Oehler et al., 2005; Byrne et al., 2013], as due to the subsidence of a hypovolcanic complex [Gailler and Lénat, 2012], or as purely regressive erosional structures [Salvany et al., 2012]. These cirques provide an exceptional opportunity to access the inner structure of the basaltic edifice.

The deepest observed unit is an intrusive body of layered gabbro, outcropping at the kilometer scale in the cirque of Salazie [Upton and Wadsworth, 1972]. Geophysical surveys and drilling revealed that this gabbroic body is at least $10 \mathrm{~km}$ in diameter [Demange et al., 1989; Malengreau et al., 1999; Gailler and Lénat, 2012]. The gabbro is covered by a breccia unit made of basic eruptive products, interpreted as a debris avalanche deposit. The basic breccia unit is covered by differentiated products, suggesting that it is older than the degenerative stage, though its specific age is unknown. Basic breccias are also observed in the cirques of Mafate and Cilaos and on the northern and western coasts of the island [Maillot, 1999; Bret et al., 2003; Bachèlery et al., 2003; Arnaud, 2005; Oehler, 2005]. The rest of Piton des Neiges is made of basic pahoehoe lava flows, covered by ignimbrites, alkalic differentiated lavas, and breccias belonging to the degenerative stage. 

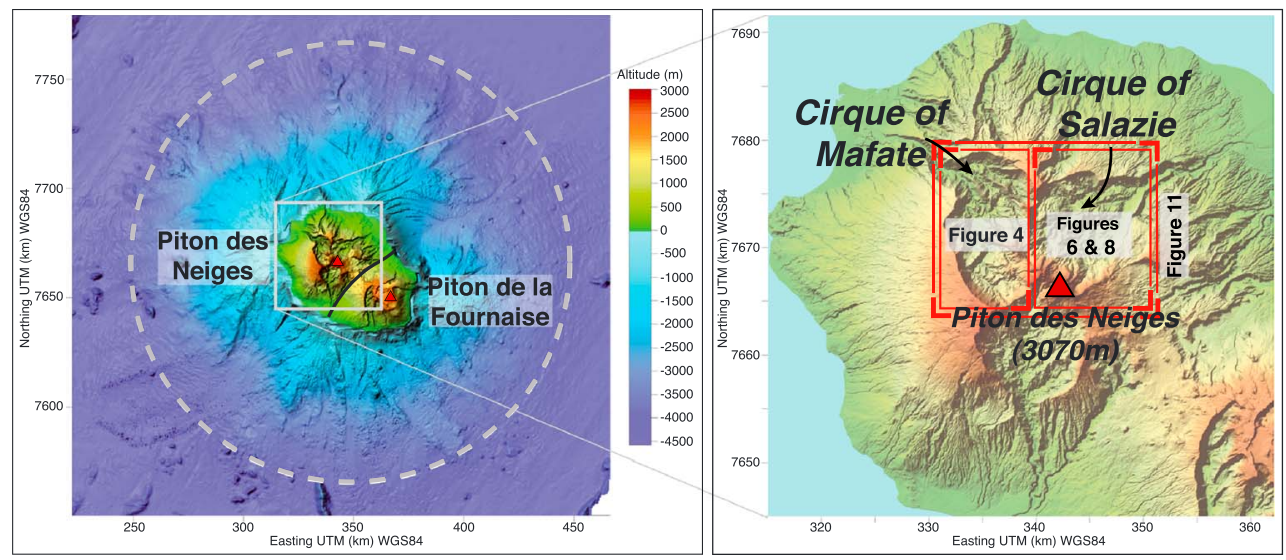

Figure 1. Submarine and subaerial relief of the La Réunion edifice. The dashed circle represents the limit of the edifice. The red rectangles show the studied areas, i.e., the cirque of Mafate in the West and the cirque of Salazie in the North.

Intrusive systems are organized along a dominant trend $\mathrm{N} 120^{\circ} \mathrm{E}$, active during the entire evolution of Piton des Neiges and well developed in the cirque of Mafate [Chevallier and Vatin-Pérignon, 1982] (Figure 2a). Other minor trends, radial to the summit of Piton des Neiges, have been proposed in the directions $\mathrm{N} 10^{\circ} \mathrm{E}, \mathrm{N} 30^{\circ} \mathrm{E}$, $\mathrm{N} 45^{\circ} \mathrm{E}, \mathrm{N} 55^{\circ} \mathrm{E}$, and $\mathrm{N} 160^{\circ} \mathrm{E}$ [Chevallier and Vatin-Pérignon, 1982; Maillot, 1999], but there is no general agreement over their existence [Michon et al., 2007].

The contact between the gabbro and the basic breccia, described as a detachment by Famin and Michon [2010], is the focus of an important northward ductile shear deformation, a greenschist-facies hydrothermal alteration, and a stack of 50-70 northward low-dipping intrusions of olivine-rich basalt (Figure 2b). These lowdipping intrusions are sills since they were intruded at a lithological discontinuity. Many intrusions also crosscut the gabbro, the breccia, and the basic lava flows and are therefore dikes since they are discordant with the country rock. Brittle deformation, consistent with an extension toward the north, is observed in the gabbro, in the pile of sills, and in the breccia at several outcrops within the cirque of Salazie.

\section{Methods}

Intrusions and brittle deformation microstructures were measured at 12 and 14 sites in the cirques of Mafate and Salazie, respectively. Given the present-day altitude of the measurement sites (300-1700 m) and the height of Piton des Neiges (from $4300 \mathrm{~m}$ in the shield-building stage to $3070 \mathrm{~m}$ in the present), the data are estimated to be representative of the intrusive activity and deformation at depths of 1400 to $4000 \mathrm{~m}$ under the summit in the edifice.

The data were measured and processed following the recommendations of Delvaux and Sperner [2003] and Sperner and Zweigel [2010]. These recommendations include the search for chronological relationships in the field, the attribution of a confidence level to each datum, and the nonautomated separation of data into mechanically compatible subsets. Intrusions and deformation data were treated separately in order to obtain independent solutions and to check their consistency. Intrusions (dikes and sills) were considered as extension fractures according to the field observation of kinematic markers of mode I opening in some of them (Figure 2c); it should be noted that some others may actually be tension-shear fractures, i.e., hybrid fractures with both opening and shear displacements (see section 5.5). Intrusions were first classified according to their field-observed basic or differentiated composition and relative chronology (Figure 3a) and then into subsets of similar orientations (trend and dip). Deformation data include faults with slickensides (Figure 2d) or with a known sense of movement, and nonmagmatic extension fractures occasionally filled with secondary minerals (Figure 2e). Fault-slip data and nonmagmatic extension fractures were manually sorted according to their crosscutting relationships (Figures 3b-3d), kinematics, and orientation. Intrusion and deformation data were processed using the Rotational Optimization method included within the TENSOR software [Delvaux and Sperner, 2003]. This method is an iterative direct inversion procedure based on the following assumptions: (1) The rock is isotropic (even if prefactured) and behaves as a linear elastic material around the 

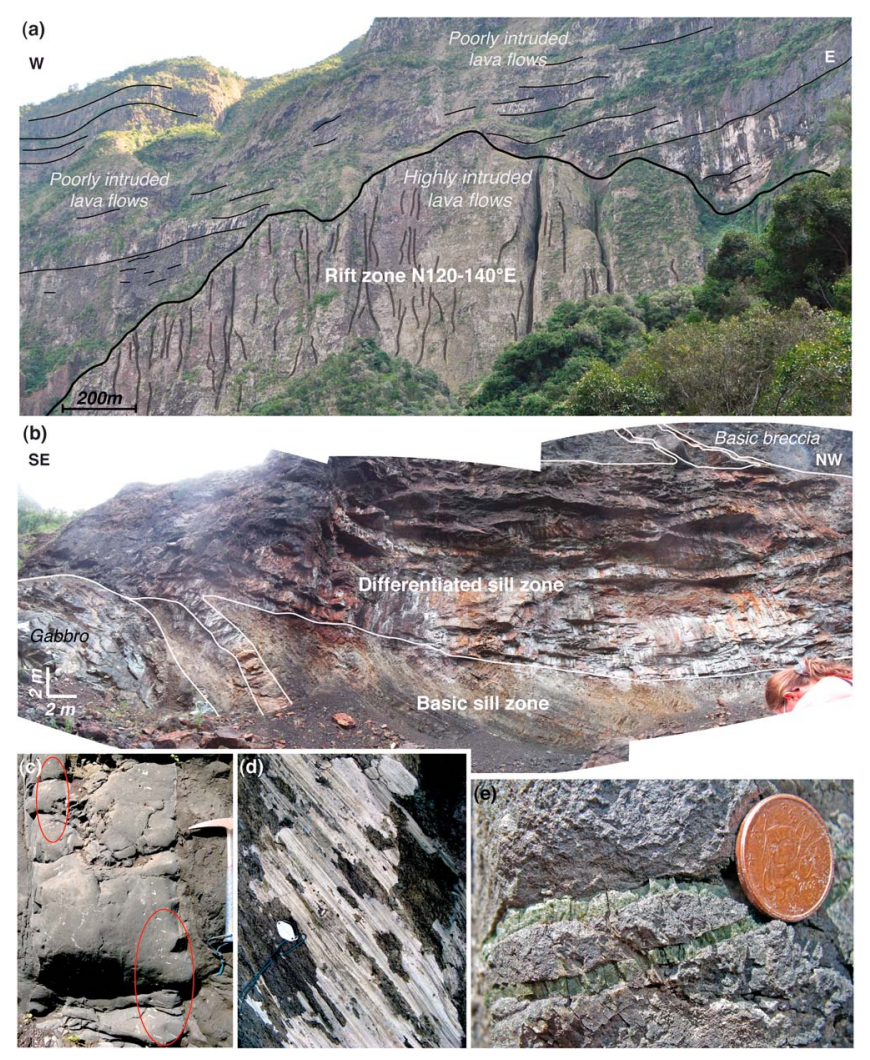

Figure 2. Geological markers of magmatic activity and deformation at Piton des Neiges. (a) Subvertical intrusions, here concentrated in the $\mathrm{N} 120-140^{\circ} \mathrm{E}$ rift zone observed in the cirque of Mafate. The discordance (bold black line) between highly intruded and overlying poorly intruded basic lava flows suggests that the rift zone ceased its activity during the shield-building stage (site Pah14). (b) Subhorizontal intrusions, here concentrated as a "sill zone" between a gabbroic body and a basic debris avalanche breccia. The sill zone is composed of a basic pile of sills, crosscut by a later, differentiated pile of sills (site SZ1). (c) Basic dike intruded in the basic breccia. Elongated bubbles near the intrusion walls are symmetric, providing evidence that the intrusion opened as mode I fracture (site Bb5). (d) Zeolite slickenfibers on a fault plane in the basic breccia (site Bb3). (e) Subhorizontal extension fractures filled with secondary minerals of the greenschist facies (chlorite, serpentine) within a sill. Note the orientation of mineral fibers indicating mode I opening (site SZ2).

fractures, i.e., stress and strain are coaxial according to Hooke's law; (2) fractures displacements are small compared to the representative element volume of the rock mass; (3) the fractures do not interact with each other; and (4) for faults, the slip vector on each fault plane is collinear to the maximum shear stress on the fault plane (the Wallace [1951] and Bott [1959] hypothesis).

The elastic behavior of rocks for small displacements on short time intervals has been confirmed by mechanical tests [Birch, 1961] and by seismology [Aki and Richards, 2002]. As shown by Pollard and Muller [1976], the assumption of a linear elastic medium is also reasonable for the analysis of magma intrusionrelated deformations. Some authors consider, however, that inversion of fault-slip data is not a reliable means by which to determinate paleostresses [e.g., Twiss and Unruh, 1998; Gapais et al., 2000; Kaven et al., 2011]. They argue that within a fault zone, stress and strain are not coaxial and instead are more probably related by nonlinear anisotropic laws, and therefore that strain markers cannot be employed as indicators of stress. However, Lacombe's [2012] review provides ample examples of the excellent agreement between paleostresses and other stress measurement methods and concludes that, subject to a series of methodological precautions [e.g., Sperner and Zweigel, 2010], the inversion of fracture data yields reliable stress tensors.

As the orientations of slip vectors depend only on four of the six parameters of the stress tensor, only a reduced stress tensor defined by the three principal stress orientations and the stress ratio $\varphi=\left(\sigma_{2}-\sigma_{3}\right)$ / $\left(\sigma_{1}-\sigma_{3}\right)$ is actually computed [Angelier, 1975, 1984]. The Rotational Optimization method allows the combination of extension fracture and fault-slip data to constrain the reduced stress tensor. Different 


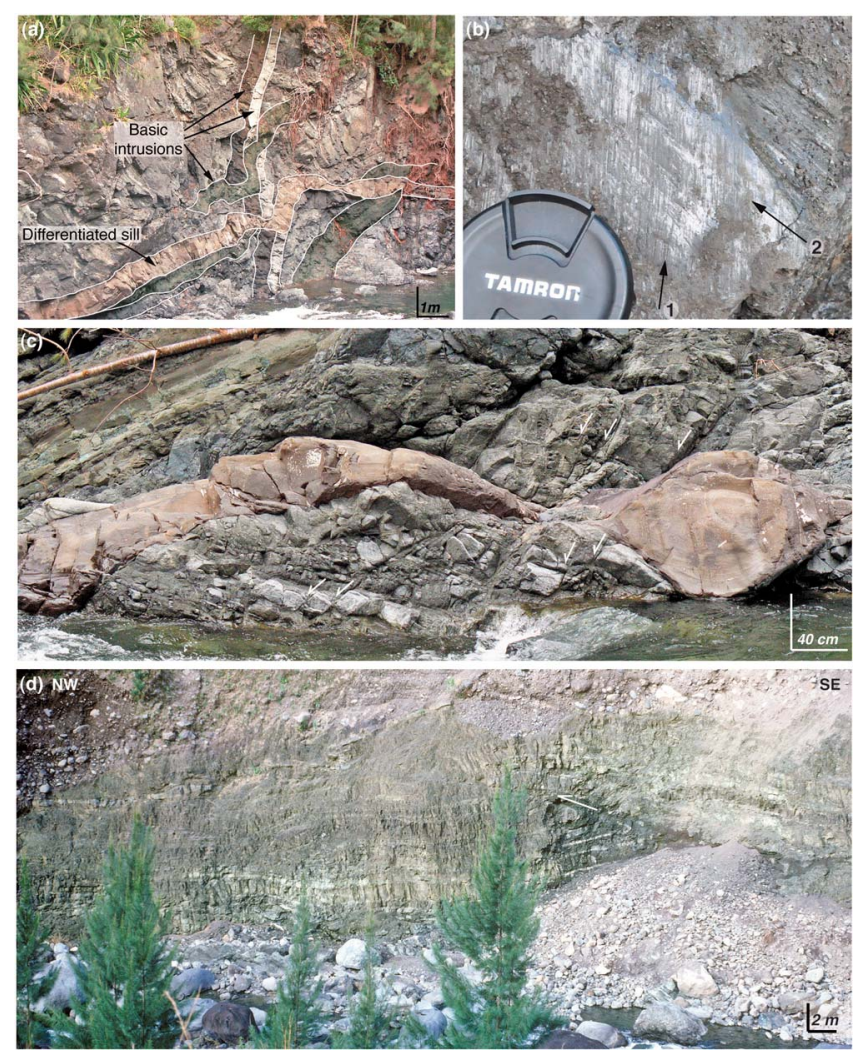

Figure 3. Markers of relative chronology in intrusions and deformation structures. (a) Mutually crosscutting basic intrusions (from the shieldbuilding stage), cut by a differentiated intrusion (from the degenerative stage, site Gab1). (b) Two generations of slickensides on the same fault plane, the second one cutting the first one (site Bb3). (c) Normal faults (white arrows) cutting the layered gabbro and intersected by a differentiated sill (site Gab1). (d) Sill zone (site SZ2) crosscut by a plurimetric thrust fault (white arrow), picture courtesy of Brian Upton.

procedures are used depending on the type of data that compose the analyzed set. For extension fractures, and thus for intrusion data, the iterative inversion aims at minimizing both the normal stress to favor opening and the shear stress to prevent slip. As it does not deal with slip deviation, the resolution of the inverse problem for extension fractures only provides a reliable orientation of $\sigma_{3}$, but not of $\sigma_{1}$ and $\sigma_{2}$. For fault-slip data, we used a composite function (function F5 in TENSOR), which primarily minimizes the slip deviation between the observed and resolved slip vectors on the plane and, in addition, maximizes the resolved shear stress magnitude and minimizes the resolved normal stress magnitude in order to favor slip on the plane. The quality of the computed stress tensors were estimated using the quality ranking system of the World Stress Map project [Sperner et al., 2003], which ranges from $A$ (best) to $E$ (worst). In the following sections, the strikes of the stress axes are expressed as angles ranging from 0 to $180^{\circ}$ from the north (clockwise) and stress orientations have thus to be read as "strike/ dip angle-dip direction" (e.g., N020/80 W).

\section{Results}

\subsection{Cirque of Mafate}

\subsubsection{Intrusions}

Two categories of intrusion composition were observed in the field. Basic intrusions, made of dark basalt containing up to $35 \%$ in volume of olivine phenocrysts, variably altered in the greenschist facies, are attributed to the shield-building stage of Piton des Neiges. Differentiated intrusions, made of light-colored unaltered trachybasalt to trachyte and syenite, are attributed to the degenerative stage. In the cirque of Mafate, more than 330 intrusions were measured at 12 measurement sites. Basic intrusions and differentiated intrusions represent $93 \%$ and $7 \%$ of the data, respectively. Both types are found in the basic pahoehoe lava flows and in the basic breccia. At the majority of sites (11/12), the intrusions are dikes oriented ESE-WNW to 

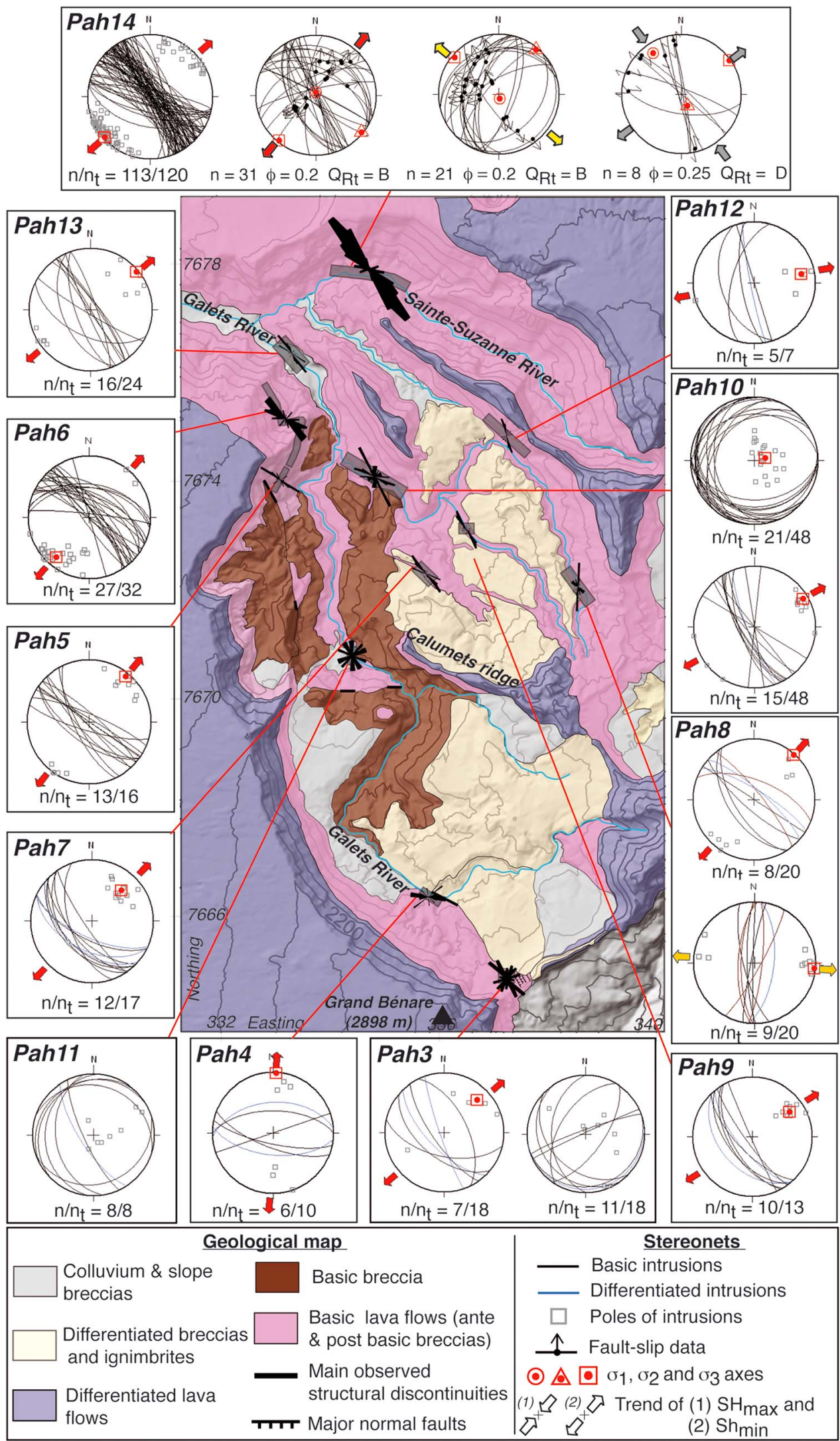

\section{Stereonets}

- Basic intrusions

- Differentiated intrusions

$\square \quad$ Poles of intrusions

^ـ Fault-slip data

$\odot \triangle \square \sigma_{1}, \sigma_{2}$ and $\sigma_{3}$ axes

(1) $\Omega$ (2) \& Trend of (1) $\mathrm{SH}_{\max }$ and

$\begin{array}{lll} & \text { (2) } \mathrm{Sh}_{\min }\end{array}$ 

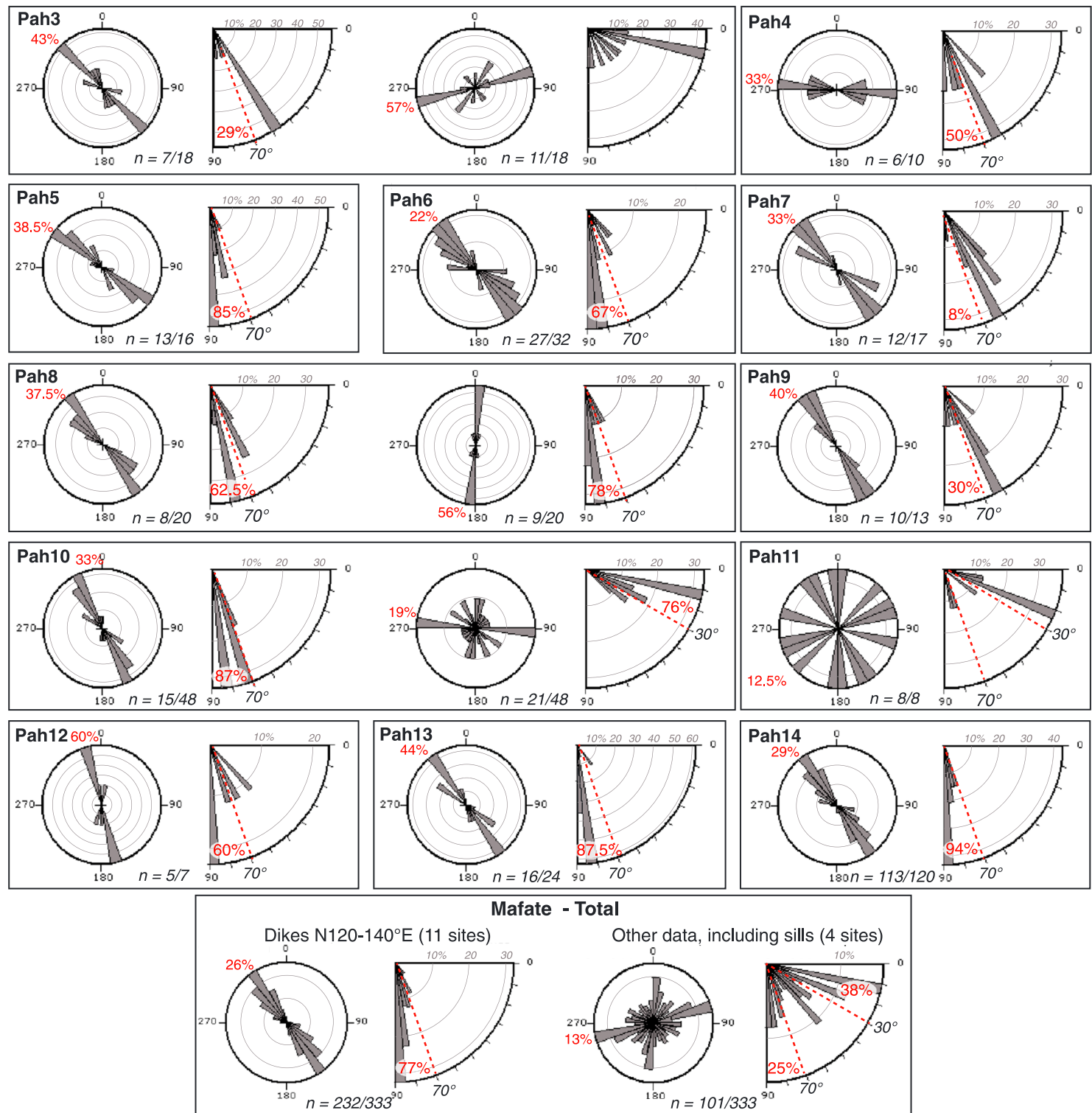

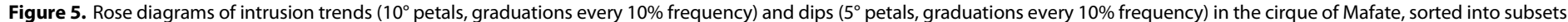

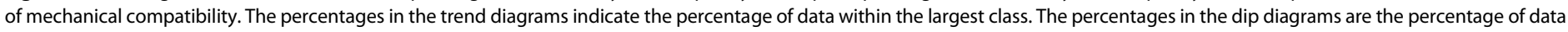

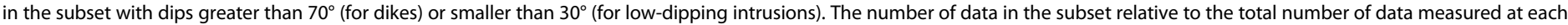
site is represented by $n$.

SSE-NNW (Figure 4), of which $77 \%$ have dips $\geq 70^{\circ}$ (Figure 5). This preferential orientation of intrusions is consistent with $\sigma_{3}$ being oriented N046/10 $\mathrm{E}$ on average. Four sites contain exceptions: One has dikes consistent with $\sigma_{3} \mathrm{~N} 095 / 3^{\circ} \mathrm{E}$ (Pah8), one has subhorizontal sills parallel to the lava flows and consistent with a subvertical orientation of $\sigma_{3}$ (Pah10), and two have no preferential orientation of intrusions (Pah3, Pah11).

Intrusions are heterogeneously distributed over the cirque of Mafate. Eighty-nine percent of the data were collected north of the Calumets ridge, with an obvious maximum density in the Sainte Suzanne River

Figure 4. Intrusions and fault-slip data for the cirque of Mafate and related stress orientations. Grey boxes on the map indicate the area of each measurement site, and rose diagrams $\left(10^{\circ}\right.$ petals) represent the trends of all intrusions at this site with a size proportional to the number of data. On the stereo diagrams (equal area projections, lower hemisphere), red, yellow, and grey arrows represent the orientation of horizontal principal stresses $\mathrm{Sh}_{\min }$ (pointing outward) and $\mathrm{SH}_{\max }$ (pointing inward) for the dominant extension, the secondary extension and the strike slip regime, respectively. The number of data in the subset relative to the total number of data measured at each site is represented by $n / n_{t} \cdot \varphi=\left(\sigma_{2}-\sigma_{3}\right) /\left(\sigma_{1}-\sigma_{2}\right) . \mathrm{QR}$ is a quality estimator of the $\varphi$ ratio, ranging from $\mathrm{A}$ (best) to $\mathrm{E}$ (worst). Map coordinates are in universal transverse Mercator (UTM) (km) World Geodetic System (WGS) 84. 
Table 1. Paleostress Tensors Computed From Intrusions and Brittle Deformation Microstructures in the Cirques of Mafate and Salazie

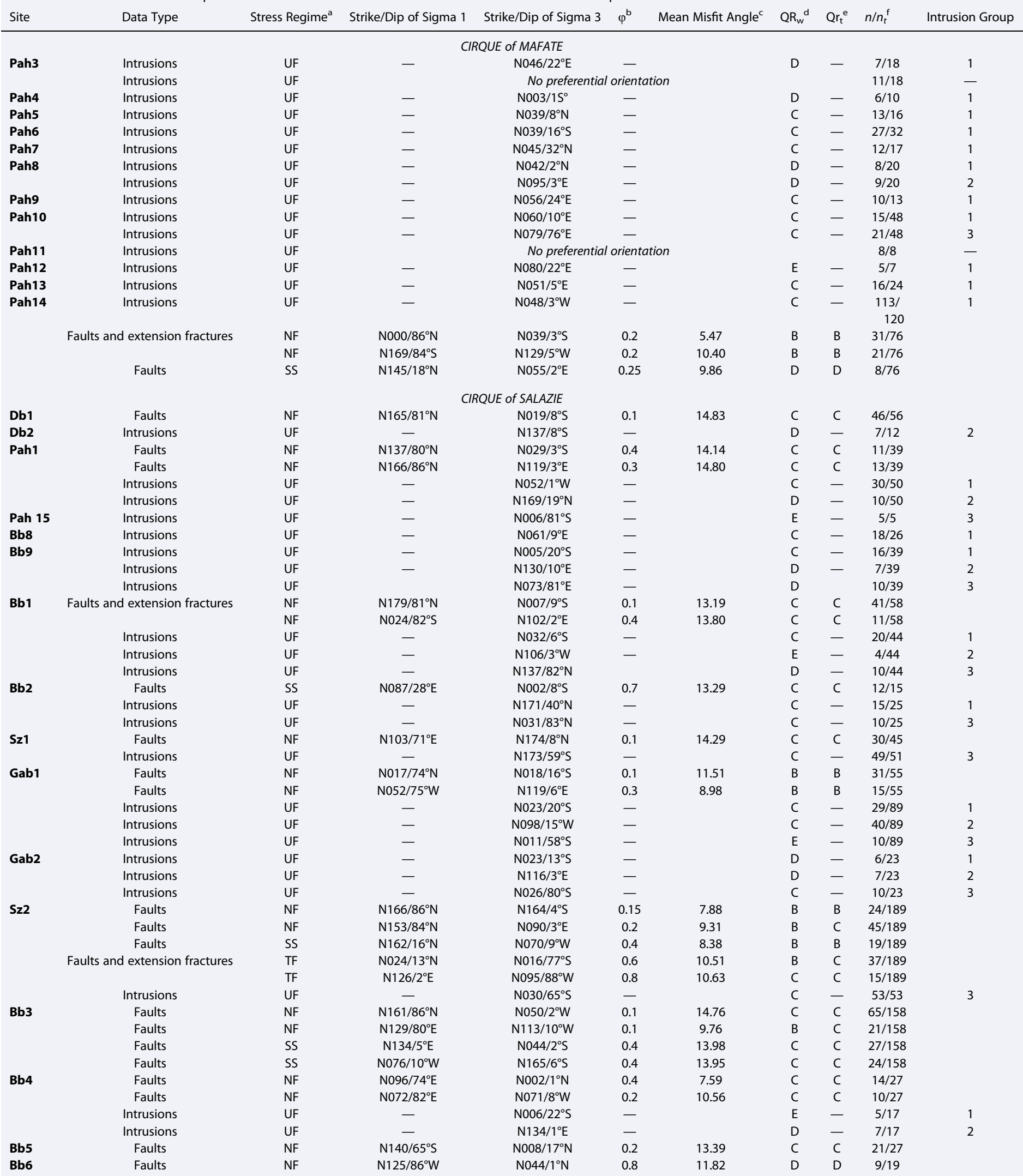


Table 1. (continued)

\begin{tabular}{|c|c|c|c|c|c|c|c|c|c|c|}
\hline Site & Data Type & Stress Regime ${ }^{a}$ & Strike/Dip of Sigma 1 & Strike/Dip of Sigma 3 & $\varphi^{\mathrm{b}}$ & Mean Misfit Angle ${ }^{c}$ & $\mathrm{QR}_{\mathrm{w}}{ }^{\mathrm{d}}$ & $\mathrm{Qr}_{\mathrm{t}}^{\mathrm{e}}$ & $n / n_{t}^{f}$ & Intrusion Group \\
\hline \multirow[t]{3}{*}{ Bb7 } & Faults & $\mathrm{NF}$ & $\mathrm{N} 025 / 80^{\circ} \mathrm{N}$ & $\mathrm{N} 037 / 10^{\circ} \mathrm{S}$ & 0.3 & 10.61 & B & $C$ & $16 / 16$ & \\
\hline & Intrusions & UF & - & $\mathrm{N} 077 / 17^{\circ} \mathrm{E}$ & - & & $E$ & - & $9 / 82$ & 1 \\
\hline & Intrusions & UF & - & $\mathrm{N} 058 / 63^{\circ} \mathrm{W}$ & - & & $C$ & - & $69 / 82$ & 3 \\
\hline \multirow[t]{3}{*}{ Pah2 } & Faults & $\mathrm{NF}$ & $\mathrm{N} 145 / 83^{\circ} \mathrm{N}$ & $\mathrm{N} 034 / 2^{\circ} \mathrm{S}$ & 0.2 & 7.72 & $C$ & $C$ & $12 / 40$ & \\
\hline & Faults & $\mathrm{NF}$ & $\mathrm{N} 118 / 75^{\circ} \mathrm{E}$ & $\mathrm{N} 125 / 15^{\circ} \mathrm{W}$ & 0 & 7.64 & B & C & $17 / 40$ & \\
\hline & Intrusions & UF & - & $\mathrm{N} 092 / 3^{\circ} \mathrm{E}$ & - & & $C$ & - & $21 / 26$ & 2 \\
\hline
\end{tabular}

${ }^{\mathrm{a}} \mathrm{NF}, \mathrm{TF}, \mathrm{SS}$, and UF stand for normal, thrust, strike slip, and unknown faulting regimes.

${ }^{\mathrm{b}} \varphi=\left(\sigma_{2}-\sigma_{3}\right) /\left(\sigma_{1}-\sigma_{2}\right)$.

${ }^{\mathrm{C}}$ Average angle between the observed and computed slip vectors.

${ }^{d} \mathrm{QR}_{\mathrm{w}}$ gives an estimate of the quality of paleostress orientations, from A (highest quality) to $\mathrm{E}$ (lowest quality). See Sperner et al. [2003] for details.

${ }^{e} \mathrm{Q} \mathrm{R}_{\mathrm{t}}$ gives an estimate of the quality of the $\varphi$ ratio, from $\mathrm{A}$ (highest quality) to $\mathrm{E}$ (lowest quality). See Delvaux and Sperner [2003] for details.

${ }^{\mathrm{f}} \mathrm{The} n / n_{t}=$ number of data in the subset relative to the total number of data measured at each site.

(Figure 4). The high density of intrusions, their subvertical dip, and their single orientation are consistent with the $\mathrm{N} 120^{\circ} \mathrm{E}$ rift zone proposed by Chevallier and Vatin-Pérignon [1982]. Note, however, that the western part of this rift zone appears to be inflected toward the direction $N 140^{\circ} \mathrm{E}$. Comparatively, few intrusions occur in the basic pahoehoe lava flows and breccias of the southern half of Mafate, and these intrusions are not concentrated into any zone of preferential injections.

\subsubsection{Deformation Microstructures}

Few deformation microstructures were observed in the cirque of Mafate. They were only found in the Sainte Suzanne River, where the maximum density of preferentially oriented intrusions was also observed (Figure 4). Deformation microstructures are exclusively brittle and include striated faults and extension fractures (Figures $2 \mathrm{~d}$ and 2e), both filled with secondary minerals (chlorite \pm calcite \pm zeolite). The orientation of mineral fibers indicates that the growth of these secondary minerals was contemporaneous with the displacement on the deformation microstructures. Some $57 \%$ of the deformation data are normal faults, $24 \%$ are strike-slip faults, $18 \%$ are extension fractures, and $1 \%$ are faults with an undetermined sense of slip. These data may be separated into three subsets containing neoformed and reactivated microstructures, for which the inversion yields three paleostress tensors (Figure 4 and Table 1). The largest subset, made of 18 normal faults and 13 extension fractures, yields an extensional stress tensor with the $\sigma_{3}$ axis oriented $N 039 / 3^{\circ} \mathrm{S}$ and a low $\varphi$ value of 0.2 (Table 1). This extension is consistent with the orientation of $\sigma_{3}$ deduced from the intrusions (N046/10 $\mathrm{E}$ ). The second largest subset, composed of 21 normal faults, is also compatible with an extensional tensor having the $\sigma_{3}$ axis oriented $\mathrm{N} 129 / 5^{\circ} \mathrm{W}$ and a $\varphi$ value of 0.2 (Table 1 ). A strike-slip tensor is also obtained from the third subset (eight data), with $\sigma_{1}$ and $\sigma_{3}$ oriented $\mathrm{N} 145 / 18^{\circ} \mathrm{N}$ and $\mathrm{N} 055 / 2^{\circ} \mathrm{E}$, respectively, and a $\varphi$ value of 0.25 (Table 1). No crosscutting relationships were observed in the field among the microstructures of the different subsets or between deformation microstructures and intrusions.

\subsection{Cirque of Salazie}

\subsubsection{Intrusions}

More than 540 intrusions were measured in the cirque of Salazie. Basic (aphyric and olivine-rich basalt) and differentiated (trachybasalt to trachyte and syenite) intrusions represent $78 \%$ and $22 \%$ of the measured data, respectively. Intrusions are found everywhere in the gabbro, the basic breccia, and the lavas of the shield-building stage, but with a different distribution pattern depending on their orientation and composition. The separation of intrusion data into subsets of similar orientation, and the corresponding orientation of $\sigma_{3}$, is represented in Figure 6 and Table 1. The first group of intrusions (Group 1) representing $27 \%$ of the data, comprises dikes trending E-W to NW-SE, of which $70 \%$ are dipping at over $70^{\circ}$ (Figure 7). Group 1 is consistent with $\sigma_{3}$ being oriented N030/2 $\mathrm{S}$ on average. The second group of intrusions (Group 2), representing 19\% of the data, comprises dikes with N-S to NE-SW trends and $70 \%$ having dips $\geq 70^{\circ}$ (Figure 7). Group 2 is consistent with $\sigma_{3}$ being oriented N123/2 $\mathrm{W}$ on average.

Intrusions of Groups 1 and 2 encompass the whole range of compositions from basic to differentiated and are not concentrated into obvious zones of preferential injection. The third group (Group 3) represents $42 \%$ of the intrusion data set and comprises subhorizontal intrusions with a northward (i.e., outward) dip, $49 \%$ of which are dipping less than $30^{\circ}$ (Figure 7). The $\sigma_{3}$ axis obtained from Group 3 has a subvertical dip ( $78^{\circ} \mathrm{S}$ on average). Sixty percent of Group 3 intrusions are made up of olivine-rich basalts 


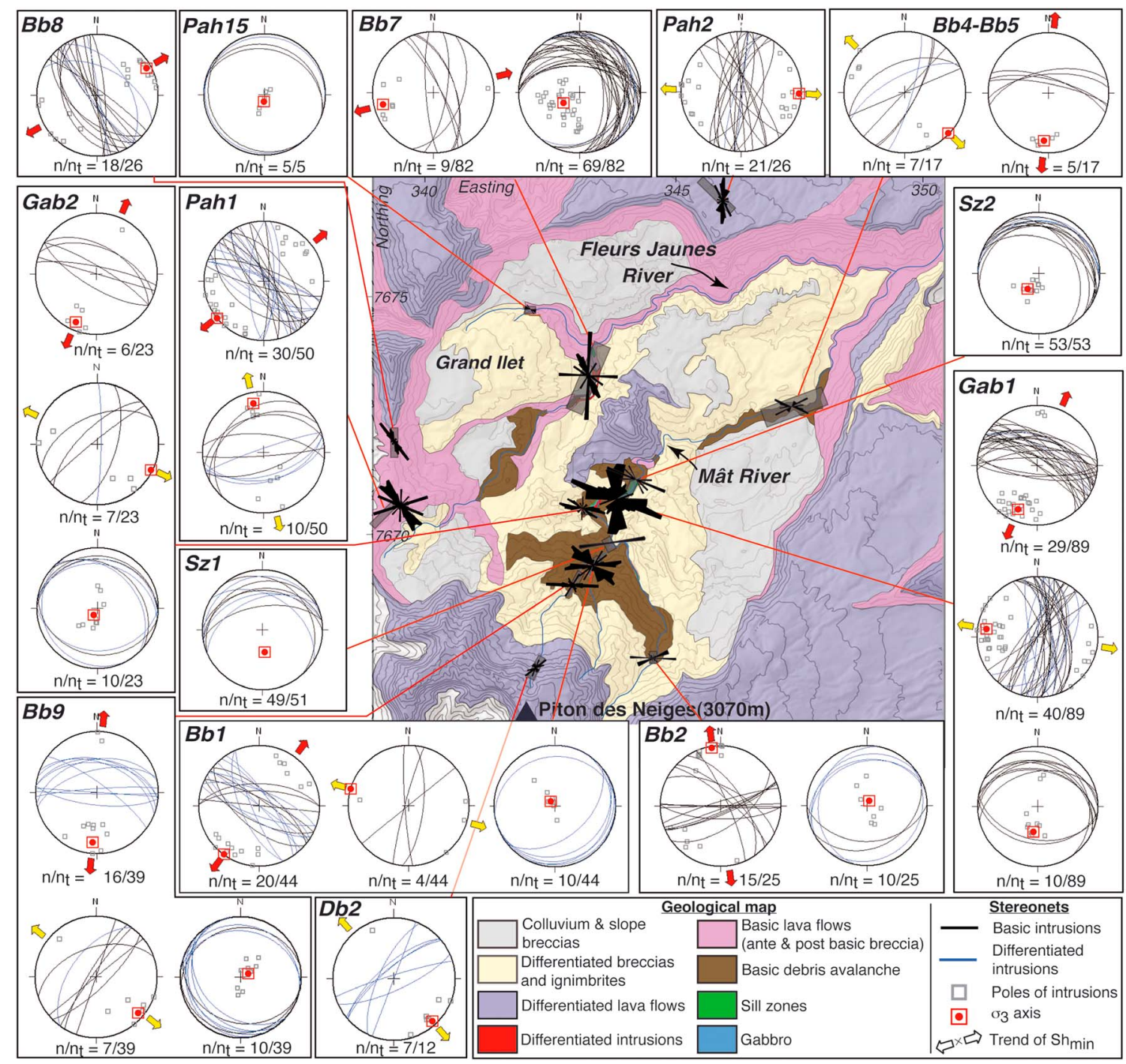

Figure 6. Intrusion data for the cirque of Salazie and calculated orientations of the minimum principal stress $\sigma_{3}$. Rose diagrams ( $10^{\circ}$ petals) represent the trends of all intrusions at each site with a size proportional to the number of data. Grey boxes on the map indicate the area of each measurement site. On the stereo diagrams (equal area projections, lower hemisphere), red and yellow arrows represent the orientation of horizontal minimum stress $\mathrm{Sh}_{\min }$ for the dominant extension and the secondary extension, respectively. The number of data in the subset relative to the total number of data measured at each site is represented by $n / n_{t}$. Map coordinates are in UTM $(\mathrm{km})$ WGS 84 .

and are concentrated as piles of sheeted sills along two lithological discontinuities. The first pile of sills is intruded in the detachment already described by Famin and Michon [2010] and is exposed at sites SZ1 and SZ2 (Figures 2b and 3d). The second pile of sills occurs in the Fleurs Jaunes River, at the contact between basic pahoehoe lava flows and the basic breccia (site Bb7). At this site, isolated (i.e., not stacked) low-dipping outward intrusions are also found intruding the basic breccia and are therefore dikes. Twelve percent of the intrusions measured in the field are not consistent with any of the three groups of intrusions and were rejected during data processing.

Two crosscutting rules were observed among the intrusions. (1) Basic intrusions of all compositions (i.e., from aphyric to olivine-rich basalt) crosscut each other but never cut differentiated intrusions, whereas differentiated intrusions cut basic intrusions (Figure 3a). (2) Mutual crosscutting among the three intrusion groups was observed. However, the number of Group 2 intrusions cutting Group 1 intrusions (nine occurrences) is greater than the reverse (only two occurrences). Similarly, the number of Groups 1 and 2 intrusions cutting Group 3 intrusions (five observed occurrences) is greater than the reverse (three occurrences). Surprisingly, however, neither of the two piles of sills has been cut by dikes. 

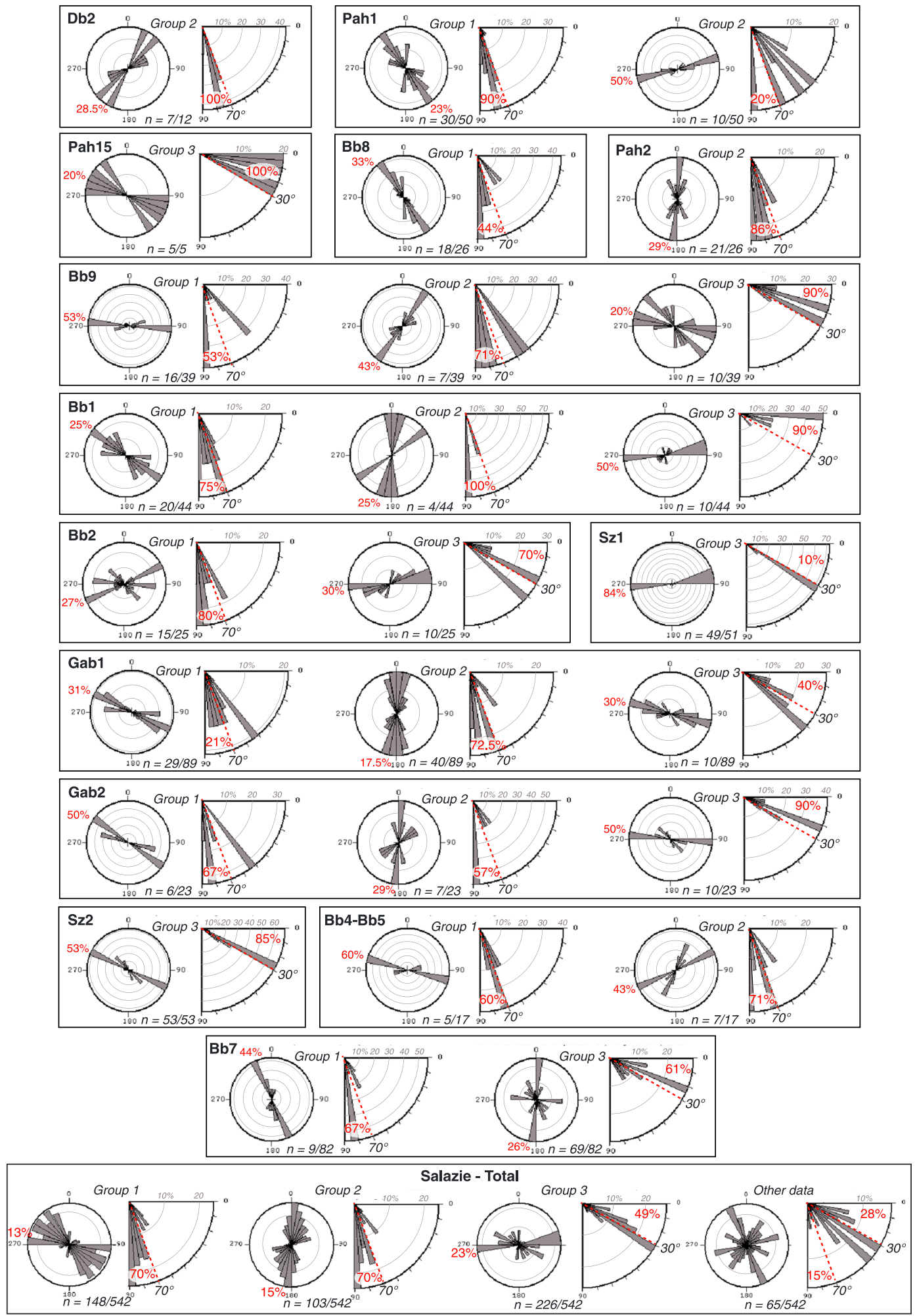

Figure 7. Rose diagrams of intrusion trends $\left(10^{\circ}\right.$ petal, graduations every $10 \%$ frequency) and dips ( $5^{\circ}$ petal, graduations every $10 \%$ frequency) in the cirque of Salazie, sorted into subsets of mechanical compatibility and classified into three groups. The percentages in the trend diagrams indicate the percentage of data within the largest class. The percentages in the dip diagrams are the percentage of data in the subset with dips greater than $70^{\circ}$ (for Groups 1 and 2) or smaller than $30^{\circ}$ (for Group 3). The number of data in the subset relative to the total number of data measured at each site is represented by $n$. 


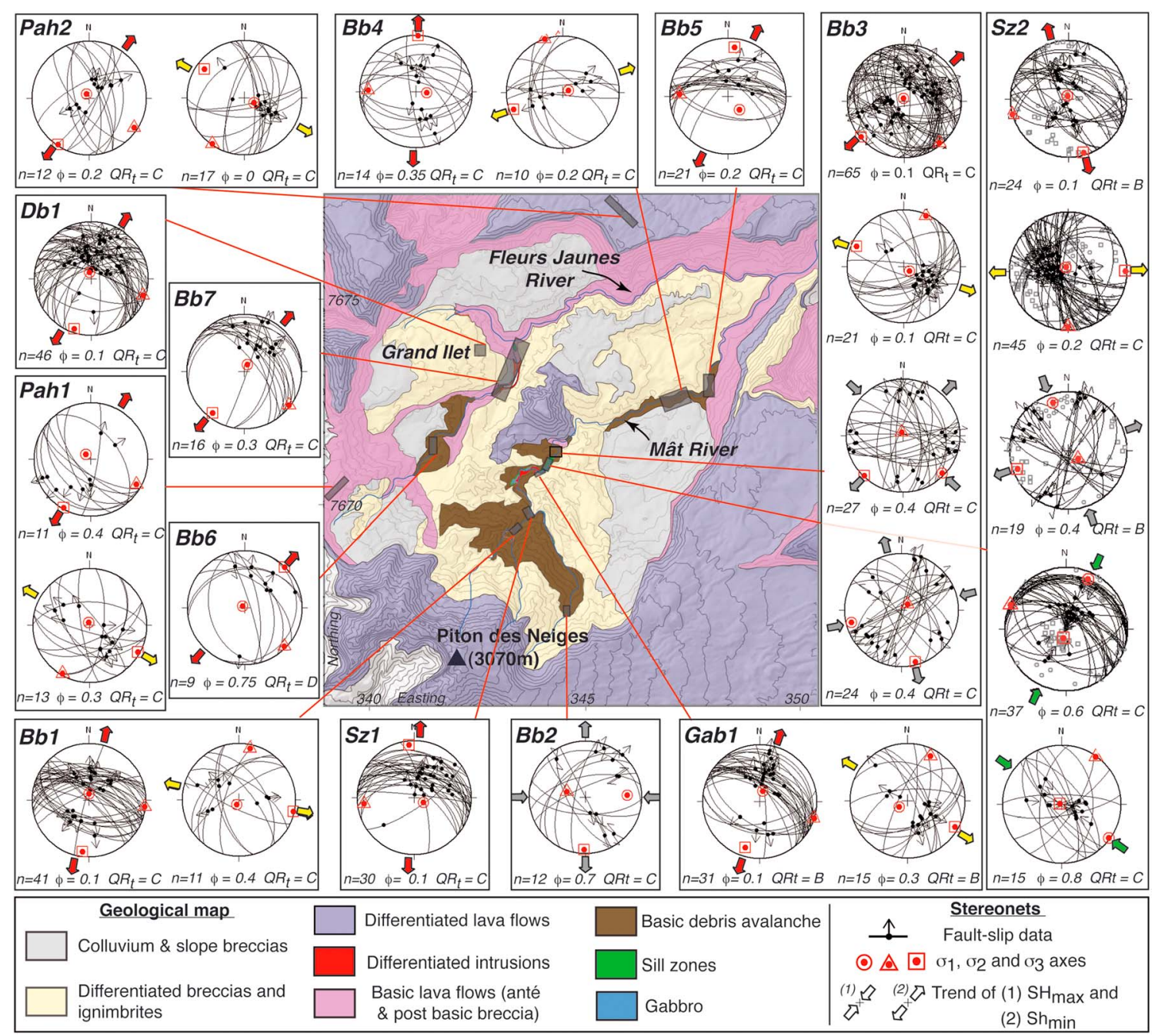

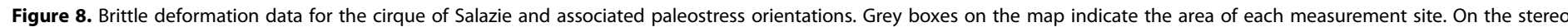

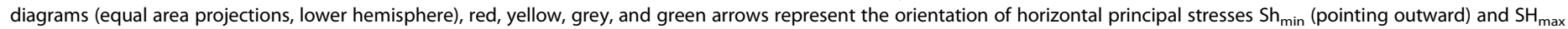

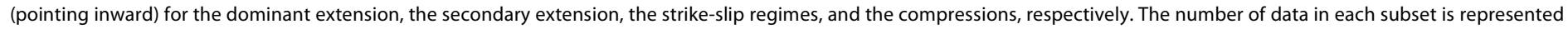
by n. $\varphi=\left(\sigma_{2}-\sigma_{3}\right) /\left(\sigma_{1}-\sigma_{2}\right)$. QR $\mathrm{R}_{\mathrm{t}}$ is a quality estimator of the $\varphi$ ratio, ranging from A (best) to $\mathrm{E}$ (worst). Map coordinates are in UTM (km) WGS 84 .

\subsubsection{Deformation Microstructures}

In contrast with the cirque of Mafate, deformation microstructures are abundant in Salazie. The deformation structures observed in the field were mostly brittle and include striated faults and extension fractures, often filled with secondary minerals of the greenschist facies (serpentine + chlorite \pm calcite \pm zeolite, Figures $2 \mathrm{~d}$ and $2 \mathrm{e}$ ). The abundance of these deformation microstructures increases toward the piles of sills both from below and above, and hydrothermal alteration also increases in these directions [Famin and Michon, 2010]. Sixty-six percent of the deformation microstructures are normal faults, $20 \%$ are strike-slip faults, $9 \%$ are thrusts, and $3 \%$ are extension fractures ( $2 \%$ are faults with an undetermined sense of slip). The deformation is therefore dominated by normal faulting. Faults are observed in the gabbro, in the piles of sills of the Mât River, in the basic breccia, and in the lava flows of the shield-building stage, but not in later units of the degenerative stage. The only exception is the differentiated breccia of Grand llet (site Db1, Figure 8). Extension fractures are observed only in the pile of sills of the Mât River and in the basic breccia at site Bb1 (Table 1).

Brittle deformation microstructures and their stress tensor solutions are presented in Figure 8. The parameters of the tensors are also provided in Table 1. Normal faults are compatible with two directions of extension. One extension, obtained at 12 sites in the cirque of Salazie and compatible with the largest subset of data (43\% of the data used in the processing), has $\sigma_{3}$ oriented NNE-SSW (N018/2 ${ }^{\circ} \mathrm{S}$ on average) and low $\varphi$ values 
( 0.2 on average). The majority of normal faults belonging to this subset are neoformed (i.e., faults that formed and moved in a single stress field [Angelier 1994]). The other extension (seven tensors, $18 \%$ of the data used in the processing) is found in the gabbro, the pile of sills SZ2 and several outcrops of basic breccia in the Mât River (Figure 8). Its $\sigma_{3}$ axis lies in the direction ESE-WNW (N106/3 $\mathrm{W}$ on average) and has low $\varphi$ values ( 0.2 on average). This secondary extension is obtained with neoformed faults and reactivated faults (i.e., faults that formed in a stress field and moved afterward in another stress field) from the former extensional tensor. Importantly, the two directions of extension are nearly perpendicular to each other at all the different sites. Strike-slip faults also yield two stress tensors displaying roughly orthogonal orientations of their minimum and maximum stress axes. The first strike-slip tensor determined in the pile of sills SZ2 and the basic breccia (sites SZ2 and Bb3, two tensors, $6 \%$ of the data used in the processing) has a $\sigma_{1}$ axis trending SSE-NNW (N148/ $11^{\circ} \mathrm{N}$ in average), while the second strike-slip tensor determined from data in the sole basic breccia (sites Bb2 and $\mathrm{Bb3}$, two tensors, $5 \%$ of the data used in the processing) has a $\sigma_{1}$ axis trending ENE-WSW (N082/18 ${ }^{\circ} \mathrm{E}$ in average). The data yielding these two strike-slip tensors by inversion are neoformed strike-slip faults and normal faults from the two extensions which were reactivated in strike-slip. Thrust faults, found exclusively in the pile of sills of the Mât river in the site SZ2 (Figure 3d), are compatible with two perpendicular compressions: one with $\sigma_{1}$ trending $\mathrm{N} 024 / 13^{\circ} \mathrm{N}$ (one tensor, $5 \%$ of the data used in the processing) and the other with $\sigma_{1}$ oriented $\mathrm{N} 126 / 2^{\circ} \mathrm{E}$ (one tensor, $2 \%$ of the data used in the processing). The two perpendicular compressions are obtained with reactivated normal faults from the two perpendicular extensions. A noticeable feature of all these tensors is their common directions of principal stress axes.

Contradictory crosscutting relationships are observed among deformation microstructures of each tensor type. Indeed, eight chronological criteria observed in the field (e.g., two slickenside lineations on the same fault plane, one intersecting the other; Figure 3b) show that the NNE-SSW extension predates the ESE-WNW extension, but five are consistent with the reverse chronology. Similarly, we observed eight criteria showing that the two extensions predate the strike-slip regime and seven with the opposite chronology. No relationships have been found between thrust faults and other microstructures, yet the occurrence of highangle and low-angle fault planes in the extensional and compressional regimes suggests mutual reactivations of these faults under two stress states. As a general rule, basic intrusions are more affected by brittle deformation microstructures than differentiated intrusions. Nevertheless, mutual crosscutting relationships were also observed between intrusions of the three groups and brittle deformation structures compatible with the computed stress tensors (Figure 3c).

\section{Discussion}

\subsection{Repartition and Chronology of Magmatism and Paleostresses}

Our results show that the intrusion of magma proceeded differently in the cirques of Mafate and Salazie. In Mafate, injections are mostly subvertical dikes with a single orientation. These dikes are concentrated into a wide zone of preferential injection in the northern part of the cirque, which may be interpreted as a $\mathrm{N} 120-140^{\circ} \mathrm{E}$ diffuse and curved rift zone. Sills were only observed at one location in Mafate. In Salazie, there are three major populations of injections perpendicular to each other. Group 1 (i.e., the ESE-WNW population) is consistent with the orientation of dikes in Mafate. Dikes of Group 1 and low-dipping intrusions of Group 3 are more abundant on the southern part of Salazie, whereas dikes of Group 2, the NNE-SSW population, are found everywhere in the cirque and on the northern slopes of Piton des Neiges. Of these three populations of intrusions, only the population of subhorizontal intrusions is concentrated into narrow zones of preferential injections (Figures $2 b$ and 3d). Such a concentration of intrusions into "sill zones", as opposed to the rift zones of Hawaiian volcanoes, is shared by several volcanoes in the Canary Islands [Cendrero, 1970; Staudigel and Schmincke, 1984; Staudigel et al., 1986; Fernández et al., 2002; Ancochea et al., 2008].

Deformation was only observed at a single site in Mafate, whereas it is widespread in the cirque of Salazie (13 sites). Deformation microstructures are also 10 times less abundant in Mafate than in Salazie. However, there is a good consistency in the stress orientations between the two cirques (Figures 4 and 8 and Table 1): The dominant stress regime is an extension toward the NNE-SSW found at 13 of the 14 deformation sites. In both cirques, a secondary perpendicular extension is obtained, never alone but always in association with the dominant NNE-SSW extension ( 8 of the 14 sites). Few strike-slip stress regimes are obtained in both cirques (four sites), but wherever they are, their $\sigma_{3}$ axis is in general agreement with either of the two extension stress regimes. The two 


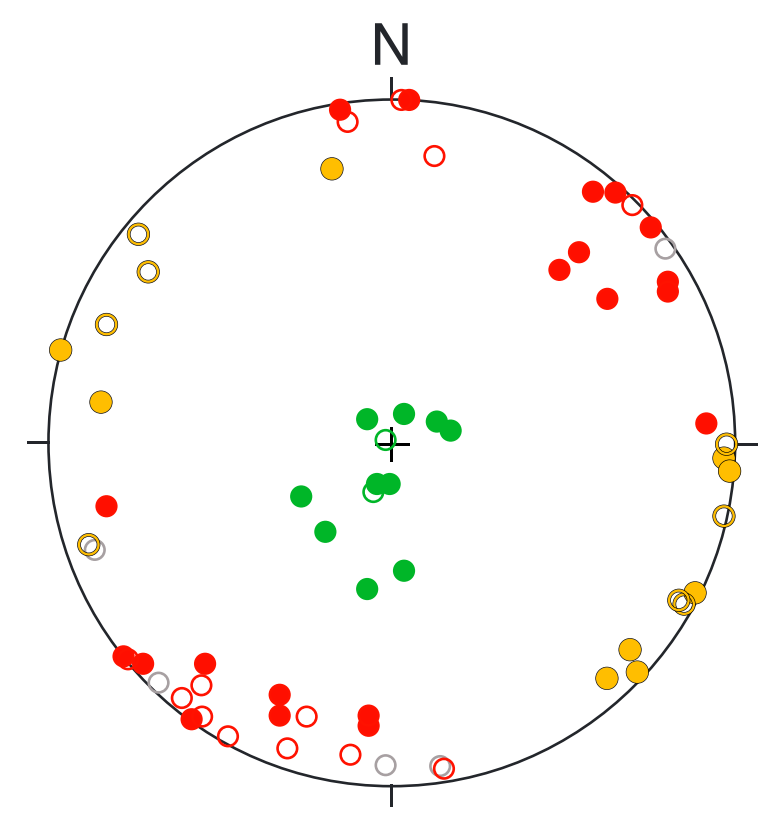

Figure 9. Orientation of the minimum principal stress $\sigma_{3}$ axis for the paleostress tensors determined at each site from intrusions (filled circles) and fault-slip data (empty circles) in the whole cirques of Mafate and Salazie. Red, yellow, grey, and green colors represent the dominant NNE-SSW extension (33 stress inversions), the secondary ESE-WNW extension (17 inversions), the strike-slips (5 inversions), and the compressions (12 inversions), respectively.

perpendicular compressions are restricted to the cirque of Salazie in the vicinity of the Mât River sill zone (one site), and their principal stress axes are subparallel to the axes of the other stress tensors.

There is also a striking consistency between the orientation of $\sigma_{3}$ deduced from intrusions and from fault-slip data in the two cirques (Figures 4, 6, 8, and 9 and Table 1). In Mafate, the orientation of $\sigma_{3}$ calculated from the dikes in the Sainte Suzanne River (N048/3 ${ }^{\circ} \mathrm{W}$ ) is compatible in terms of trend and dip with the orientation of $\sigma_{3}$ in the extensional and strike-slip tensors determined from deformation microstructures (N039/3 $\mathrm{S}$ and $\mathrm{N} 055 / 2^{\circ} \mathrm{E}$, respectively; Table 1 ). In the cirque of Salazie, intrusion data are also consistent with fault-slip data at the outcrop scale (for instance, compare intrusions and deformation at site Gab1) and at the regional scale: The average orientations of $\sigma_{3}$ in Groups 1, 2, and 3 is $\mathrm{N} 030^{\circ} \mathrm{E}, \mathrm{N} 123^{\circ} \mathrm{E}$, and subvertical, respectively, whereas they are $\mathrm{N} 018^{\circ} \mathrm{E}, \mathrm{N} 106^{\circ} \mathrm{E}$, and subvertical in the dominant extension, the secondary extension, and the two compressions, respectively (Figure 9).

Olivine-rich basalts constitute the greater majority of intrusions in the sill zones of Salazie, reaching up to $90 \%$ at site SZ2. This suggests a compositional sorting of intrusions during the shield-building stage. Two mechanisms can be proposed to explain such abundance of olivine-rich basalts as sills. (1) Sills stem from a deeper, more basic reservoir than the dikes of Groups 1 and 2 that are mostly composed of aphyric basalts (60\% of basic intrusions); or (2) sills come from the base of a reservoir, enriched in olivine by crystal accumulation, and these high density magmas are more prone to propagate horizontally than other magma compositions. This second mechanism is also proposed at Piton de la Fournaise volcano and is discussed in section 5.6.

The interpreted chronology of stress regimes obtained from intrusions and fault-slip data is summarized in Figure 10. The occurrence of mutual crosscutting among the different populations of intrusions suggests that injections in the three perpendicular orientations largely overlapped in time and span from the shieldbuilding stage to the degenerative stage. Similarly, the observation of contradictory chronological criteria between deformation microstructures implies that the two perpendicular extensions, the strike-slip regimes, and the two perpendicular compressions occurred mostly during the same time interval. Given the mutual crosscutting relationships between deformation and intrusions, these stress regimes occurred mostly during shield building and vanished in the degenerative stage.

In summary, there is a good consistency between (1) the local direction of $\sigma_{3}$ determined individually from intrusion and deformation data at each site, (2) the regional predominance of a $\mathrm{N} 120-140^{\circ} \mathrm{E}$ dike trend and a 


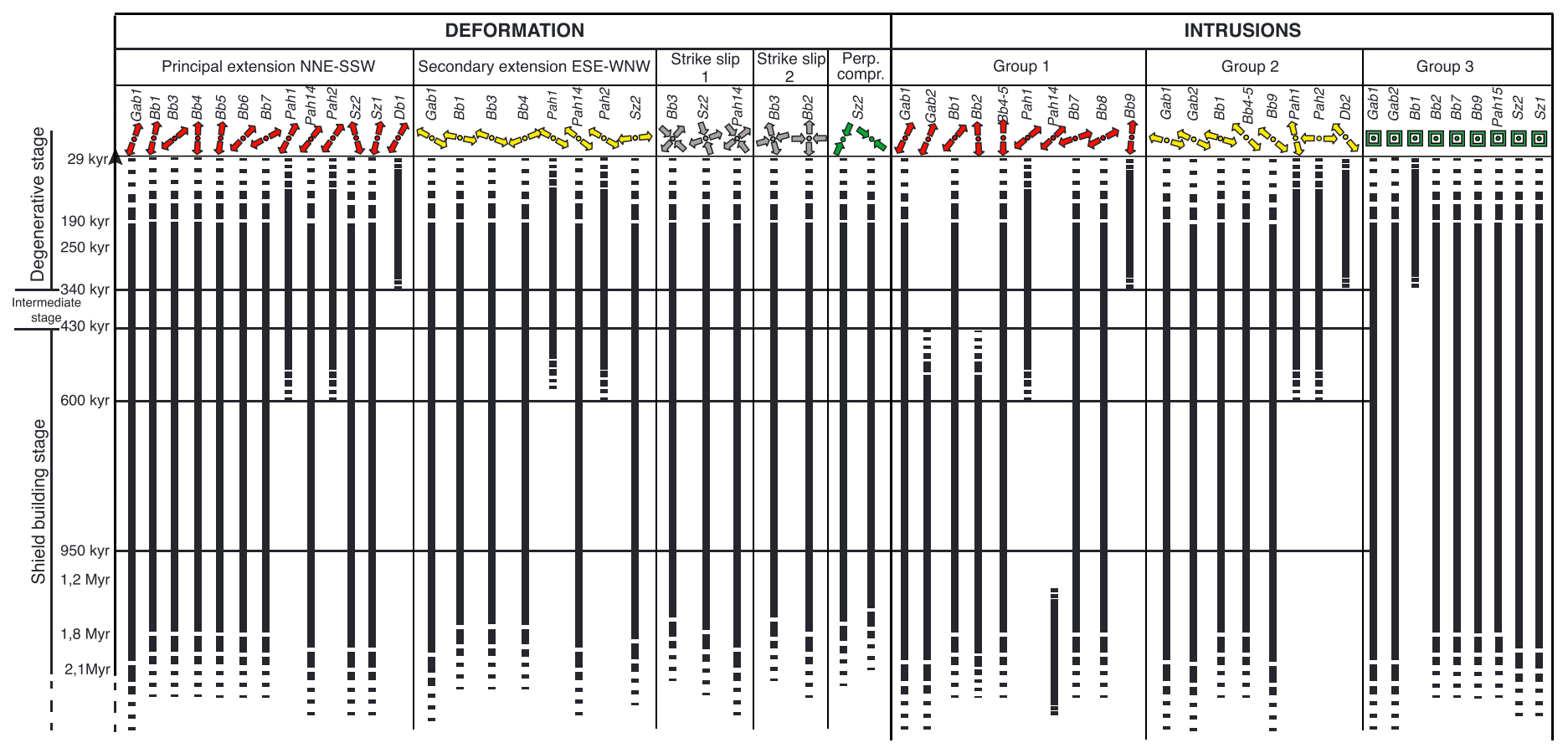

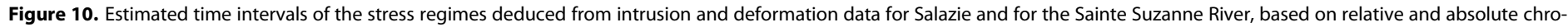

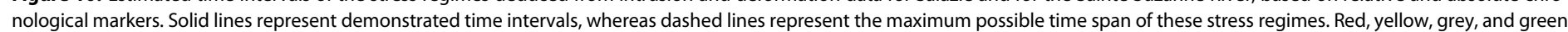

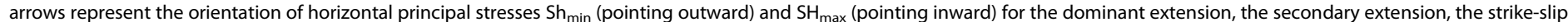
regimes, and the compressions, respectively. Green squares show the principal minimum stress $\sigma_{3}$ axis, subvertical for the sills of the Group 3 .
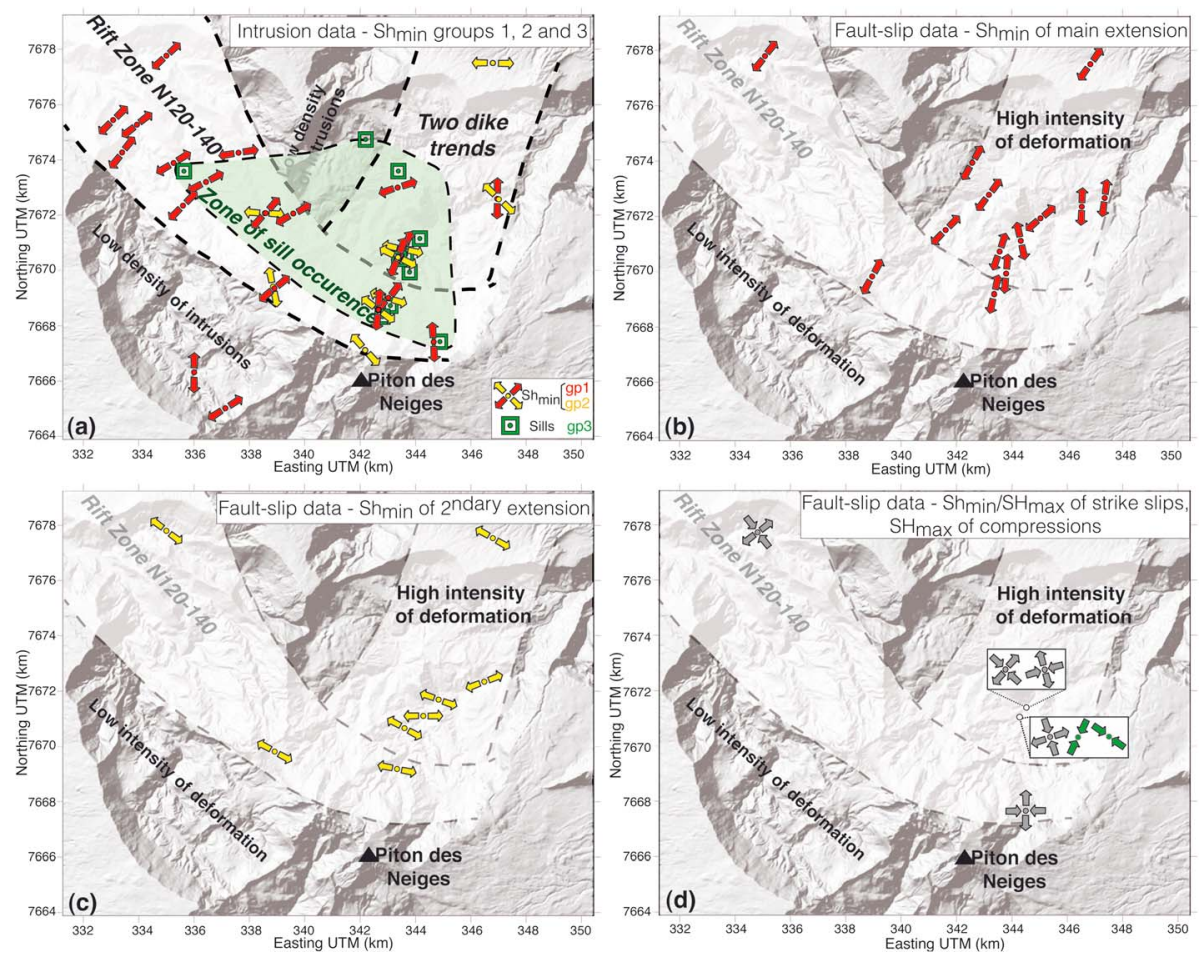

Figure 11. (a) Orientation of the horizontal minimum stress $\mathrm{Sh}_{\min }$ deduced from the three groups of intrusions. The green squares symbolize the sills. (b) Orientation of $\mathrm{Sh}_{\min }$ from tensors of the main extension (i.e., containing the largest subset of fault-slip data). (c) Orientation of $\mathrm{Sh}_{\min }$ from secondary extensional tensors. (d) Orientation of $\mathrm{Sh}_{\min }$ and $\mathrm{SH}_{\max }$ (maximum horizontal stress, pointing inward) for strike-slip and compressional tensors (in grey and green, respectively). 
mechanically compatible NNE-SSW extension in the two cirques, and (3) the coexistence, during the same time interval, of perpendicular intrusion populations and perpendicular extensional, strike-slip, and compressional stress regimes with parallel principal stress axes (Figure 11). This general consistency of intrusions and deformation structures at the local and regional scales strongly supports a posteriori the validity of our two independent inversion procedures. This, in particular, suggests that mode I opening is a realistic assumption for the majority of intrusions and that our stress tensor solutions represent true stress states applied contemporaneously to the intrusive activity of Piton des Neiges.

\subsection{Regional Volcano-Tectonics}

Our analysis of intrusions and deformation structures at Piton des Neiges shows that the northern part of the edifice was essentially under an extensional state of stress from its shield-building to its degenerative stage and from a depth of 1.4 to $4 \mathrm{~km}$. The dominant direction of extension was NNE-SSW (Figures 9 and 11). It is very tempting to attribute this dominant extension to a crustal tectonic stress field at the regional scale, as proposed for several oceanic basaltic shields in Hawaii [MacDonald, 1972; Walker, 1990] and in the Canary Islands [Anguita et al., 1991; Marinoni and Pasquarè, 1994; Geyer and Martì, 2010]. The crustal structure in the vicinity of La Réunion Island consists of a $\mathrm{N} 120^{\circ} \mathrm{E}$ paleoridge and two N030 $\mathrm{E}$ transform faults, all inactive since $\sim 60$ Ma [Dyment, 1991]. A slight crustal doming is also observed underneath La Réunion, interpreted as an isostatic uplift due to the thermal thinning of the oceanic lithosphere and/or to magma underplating [Michon et al., 2007]. Michon et al. [2007] proposed that this isostatic uplift reactivated the N120E paleoridge and the $\mathrm{N} 030^{\circ} \mathrm{E}$ transform faults, explaining the striking alignments of volcanic vents at La Réunion. Similarly, the N120-140 $\mathrm{E}$ rift zone of Mafate and the dominant NNE-SSW extension may also originate from this isostatic reactivation of crustal structures. Alternatively or additionally, the NNE-SSW extension of the northern part of Piton des Neiges could have also resulted in a gravity-driven extensional stress field due to the rapid growth of the edifice, which was oriented radially with respect to the summit.

\subsection{Relationship Between Intrusions and Stress Permutations}

The overlap in time of perpendicular intrusion directions and paleostress orientations indicates that the dominant NNE-SSW extension coexisted with other, perpendicular stress regimes during the same time interval. We attribute this overlap of incompatible and perpendicular stress regimes to repeated stress permutations within the volcanic edifice. Given their repeated occurrence at short timescales (i.e., $<340 \mathrm{ka}$ ) during the history of Piton des Neiges, it is unlikely that these stress permutations resulted in a regional tectonics. Besides, many numerical studies have investigated the effect of topographic loading on dike propagation [e.g., Dieterich, 1988; Cayol and Cornet, 1998; Muller et al., 2001; Watanabe et al., 2002; Pinel and Jaupart, 2004; Maccaferri et al., 2011]. In the absence of buttressed flank and of regional tectonic stress, the gravitational load related to volcano topography is responsible for the development of typical radial and annular dike patterns. Models also show that the maximum principal stress $\sigma_{1}$ is commonly reoriented subparallel to the volcano slopes when approaching the surface and that dikes might be deviated toward $\sigma_{1}$, leading to the development of low-dipping intrusions. However, several authors [e.g., Dieterich, 1988; Cayol and Cornet, 1998; Letourneur et al., 2008] have demonstrated that within a volcanic edifice, the effect of topography roughness (i.e., volcano slopes) vanishes within $1 \mathrm{~km}$ from the surface. Given the absence of radial organization of intrusions and the estimated overburden of the studied outcrops (1.4-4 km), the effect of topographic load on stress variations was thus very likely to be negligible at Piton des Neiges volcano. Numerous studies have also highlighted the influence of discontinuities and contrasting rock mechanical properties on stresses rotation and on sill emplacement [e.g., Pollard and Johnson, 1973; Gudmundsson, 2005, 2011; Gudmundsson and Loetveit, 2005; Kavanagh et al., 2006; Burchardt, 2008; Menand, 2008; Taisne and Jaupart, 2009; Maccaferri et al., 2011]. Hu and Angelier [2004] proposed that anisotropies and heterogeneities in brittle deformation favor the occurrence of stress permutations in the crust. However, stress permutations were observed at the plurikilometric scale, within different, variably altered and fractured lithologies (breccia, lava flows, gabbro, and sill zones), both close to and away from discontinuities, suggesting that mechanical heterogeneities were not the primary factor controlling these permutations at Piton des Neiges.

Nevertheless, there is a location pattern in the stress permutations. Looking at the deformation data, the permutation between the two extensions occurs at almost every site in the two cirques (Figures 11b and 11c). The strike-slip regimes associated with a NNE-SSW direction of $\sigma_{3}$ are superimposed on the dominant extension only in the rift zone of Mafate and around the sill zone of the Mât River in Salazie. The 


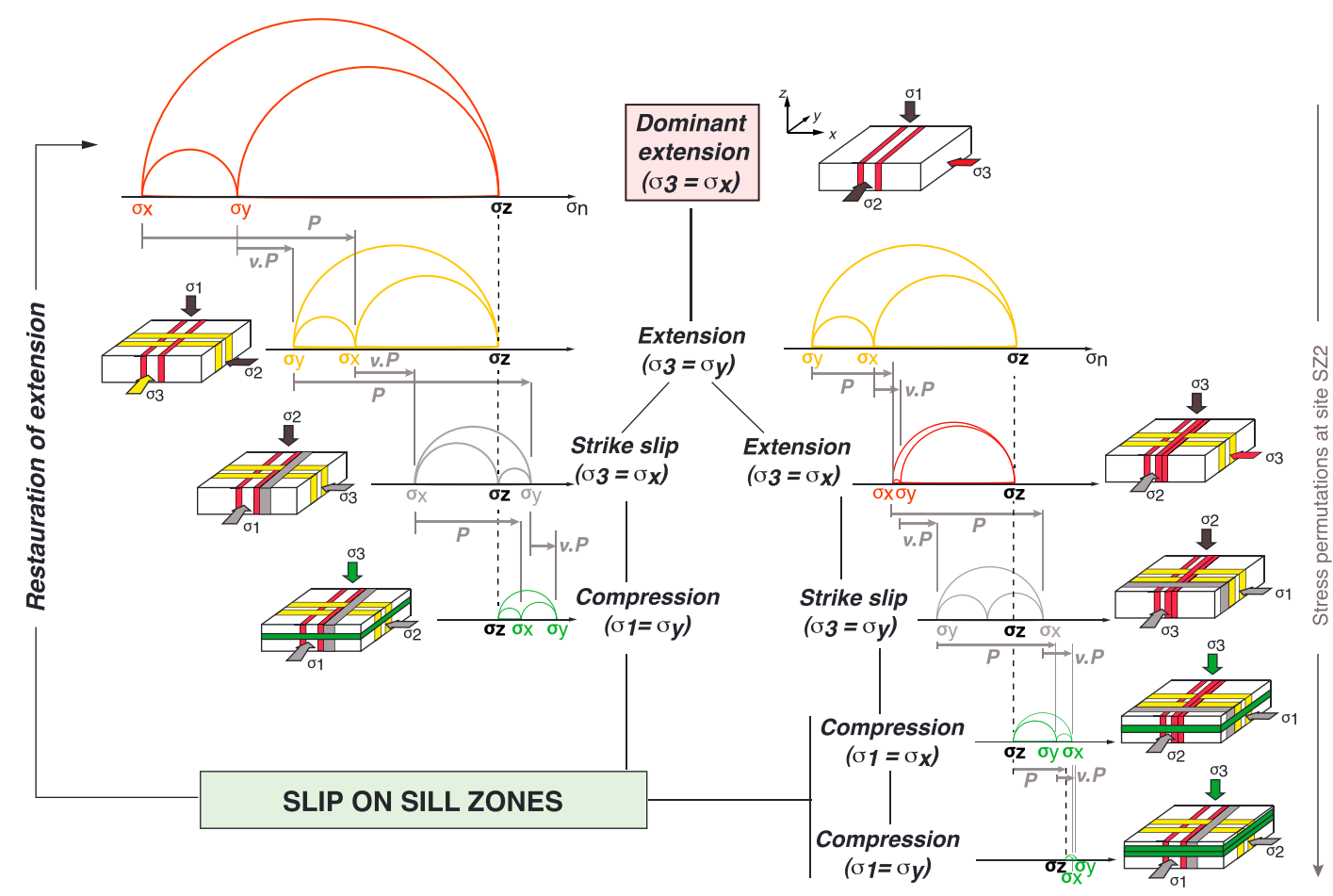

Figure 12. Conceptual model of successive stress permutations caused by repeated magma intrusions in an elastic medium (modified from Vigneresse et al. [1999]). Bloc diagrams represent intrusion orientations and crosscutting relationships. Mohr circles are dimensionless. Red, yellow, grey, and green colors represent the dominant extension, the secondary extension, the strike-slip regimes, and the compressions, respectively. The stresses in the $x, y$, and $z$ direction are $\sigma_{x^{\prime}} \sigma_{y^{\prime}}$ and $\sigma_{z^{\prime}}$ respectively. The maximum, intermediate, and minimum principal stresses are $\sigma_{1}, \sigma_{2}$, and $\sigma_{3}$, respectively. $P$ is the magma pressure and $n$ the Poisson's ratio. In a plane strain field, the effect of an intrusion is to increase $\sigma_{3}$ by a value of $P$ and $\sigma_{2}$ by a value of $v \cdot P$.

compressional regimes occur uniquely in the sill zone of the Mât River and only in addition to all the other stress fields (Figure 11d). The number of stress permutations increases in the vicinity of the two zones of maximum intrusion concentration, the rift zone of Mafate (i.e., three stress tensors and two permutations) and the sill zone of the Mât River (i.e., five stress tensors and four permutations). Stress permutations thus appear to be localized in and around the most highly intruded zones.

Several authors have suggested that stress reorientations may occur in response to magma intrusions in the crust [Parsons and Thompson, 1991; Parsons et al., 1992; Vigneresse et al., 1999; Kühn and Dahm, 2008] or in volcanoes [Geoffroy et al., 1993; Roman et al., 2004; Lehto et al., 2010]. In the model of Chadwick and Dieterich [1995] for instance, stress permutations are caused by pressure fluctuations in a magmatic reservoir, which explains the occurrence of annular and radial intrusions (ring dikes and cone sheets, respectively) on Galapagos volcanoes. This model hardly applies to Piton des Neiges, not only because we do not observe any annular or radial repartition of intrusions but also because it does not account for the occurrence of sheeted sills. Alternatively, Vigneresse et al. [1999] proposed that sheet intrusions sufficiently modify the stress state to cause permutations in their vicinity and influence the orientation of subsequent intrusions. Their model applies to the emplacement of granitic intrusions in the crust. They assume an isotropic elastic medium, a plane strain field around intrusions, and a brittle deformation of the host rock. In parallel, several analytical and numerical studies have shown that these assumptions are also valid as a first approximation for the analysis of stresses and deformation in basaltic and volcanic settings [e.g., Delaney et al., 1986; Rubin and Pollard, 1987; Chadwick and Dieterich, 1995; Walter et al., 2005; Peltier et al., 2007; Burchardt, 2008]. The theoretical developments of Vigneresse et al. [1999] are thus adapted to our case and tested hereafter. Let us consider an elastic medium in which the initial stress state is chosen to be extensional with $\sigma_{3}, \sigma_{2}$, and $\sigma_{1}$ oriented along the $x, y$, and $z$ axes, respectively (Figure 12). This initial stress field would correspond to the dominant NNE-SSW extension at Piton des Neiges. For intrusions to open, the magma pressure $P$ must exceed the value of the minimum principal stress $\sigma_{3}$ and the tensile strength of the rock $T_{0}$ (negligible for fractured basaltic rock masses [Schultz, 1995]) so that $P \geq \sigma_{3}+T_{0}$. The effect of a sheet intrusion in the $(y, z)$ 
plane (i.e., a Group 1 dike), at a magma pressure $P$, is thus to increase the stress in the $x$ direction $\left(\sigma_{x}\right)$ so that $\sigma_{x}=\sigma_{3}+P$. Like many other studies [e.g., Pollard and Holzhausen, 1979; Delaney et al., 1986; Rubin, 1993; Zenzri and Keer, 2001; Jaeger et al., 2007], Vigneresse et al. [1999] make the assumption that the effect of a dike intrusion is a plane strain field. Strain is assumed to occur in the direction of opening and in the vertical axis but is negligible in the horizontal of the intrusion plane. In plane strain, the stress acting on the $y$ axis $\left(\sigma_{y}\right)$ also increases proportionally to the Poisson's ratio $(v)$ of the surrounding rock so that $\sigma_{y}=\sigma_{2}+v \cdot P$ (Appendix A). The vertical stress $\left(\sigma_{z}\right)$ remains unchanged and is equal to $\sigma_{1}$. Because $v$ ranges between 0.15 and 0.35 for the majority of rocks, this results in $\sigma_{x}$ increasing more rapidly than $\sigma_{y}$ and eventually exceeding $\sigma_{y}$. In the latter case, $\sigma_{3}$ switches from the $x$ axis to the $y$ axis (and $\sigma_{2}$ from $y$ to $x$; Figure 12), which corresponds to a permutation between two perpendicular extensional regimes (i.e., the dominant NNE-SSW extension and the secondary ESE-WNW extension). The result is the development of a second set of subvertical intrusions along the $(x, y)$ plane (i.e., dikes of Group 2) and perpendicular to the first set (Group 1). Of course, later intrusions will cause repeated switches between the two extensional stress fields. Because $\sigma_{z}$ remains unchanged (Figure 12), further intrusions will necessarily lead to a next stage of stress permutations where $\sigma_{x}$ or $\sigma_{y}$ exceeds $\sigma_{z}$. This case results in both $\sigma_{1}$ and $\sigma_{3}$ being both horizontal and puts the stress field in the strike-slip regime (Figure 12). Two perpendicular strike-slip regimes may alternate depending on whether $\sigma_{x}$ or $\sigma_{y}$ is the maximum principal stress, as observed in the Mafate rift zone and the Salazie sill zones. The intrusions emplaced during these strike-slip regimes are still subvertical and perpendicular to each other in the planes $(y, z)$ and $(x, z)$, yielding both Groups 1 and 2 dikes.

An extreme case of stress permutation is reached when, after many subvertical intrusions, $\sigma_{x}$ and $\sigma_{y}$ both exceed $\sigma_{z}$. This extreme case results in $\sigma_{z}$ becoming equal to $\sigma_{3}$, and the stress field being in compressional regime (Figure 12). Two perpendicular directions of compression may occur depending on whether $\sigma_{1}$ is along the $x$ or $y$ axis. Intrusions emplaced under this compressional stress field are subhorizontal (i.e., belonging to Group 3 ) and may develop as sills. In that case, the direction of opening is the vertical $z$ axis, and as for dikes, no deformation is expected along the $y$ axis (plane strain). During sill intrusion, $\sigma_{z}$ (i.e., $\sigma_{3}$ ) is increased by a value of $P$ and $\sigma_{x}$ (i.e., $\sigma_{2}$ ) is increased by a value of $v \cdot P$. A stress permutation between the $x$ and $y$ axes is therefore possible, leading to a perpendicular compressional stress field as observed at site SZ2 (Figure 12). Note that if the sills are emplaced far from the flank surface so that the deformation in the $x$ direction can be neglected, a uniaxial strain field can be assumed for compression. In that case, the horizontal stresses would be increased by a value of $[v /(1-v) \cdot P]$ instead of $v \cdot P$, with no consequence on our permutation model.

The effect of heating of the rock mass around the intrusions deserves to be discussed as a possible cause of local and short-term perturbations of the stress state. A temperature increase $\left(T-T_{0}\right)$ causes a dilation of the rock, which under plane strain results in an increase of $\sigma_{x}$ and $\sigma_{y}$ by $3 \cdot \beta \cdot K \cdot\left(T-T_{0}\right)$, where $\beta$ is the thermal expansivity and $K$ is the bulk modulus of the rock, both assumed to be isotropic [Jaeger et al., 2007]. The vertical stress $\sigma_{v}$ does not change as the vertical dilation is not restrained. In the extensional regime, the ntrusion of a dike will thus cause an increase of $\left[\sigma_{3}+3 \cdot \beta \cdot K \cdot\left(T-T_{0}\right)\right] \cdot P$ and $\left[\sigma_{2}+3 \cdot \beta \cdot K \cdot\left(T-T_{0}\right)\right] \cdot v \cdot P$ instead of $\sigma_{3} \cdot P$ and $\sigma_{2} \cdot v \cdot P$, thus facilitating stress permutations. In the strike-slip regime, the thermal stress increase will apply to $\sigma_{3}$ and $\sigma_{1}$ in the same way and to $\sigma_{2}$ and $\sigma_{1}$ in compression. Heat thus favors stress permutations by increasing the magnitude of horizontal stresses but cannot be solely responsible because it is isotropic.

\subsection{Evidence of Stress Permutations at Piton des Neiges}

In addition to the prediction of perpendicular intrusions and perpendicular stress states, three other mechanical consequences of the Vigneresse et al. [1999] theory may be used to test its applicability to our case. The first obvious consequence is that stress permutations are spatially related to the vicinity of preferential pathways for intrusions. This is the case at Piton des Neiges, as the most extreme examples of permutations (strike-slip and thrust regimes) are only observed in the immediate vicinity of the N120-140 $\mathrm{E}$ rift zone in Mafate and the sill zones in Salazie.

The second mechanical consequence is that two of the three principal stresses must be close to each other in magnitude to allow stress permutations. This may be tested using the ratio $\varphi=\left(\sigma_{2}-\sigma_{3}\right) /\left(\sigma_{1}-\sigma_{3}\right)$ obtained by inversion of our fault-slip data (Table 1). Regardless of the stress regime, $0 \leq \varphi<0.5$ indicates that $\sigma_{2}$ and $\sigma_{3}$ are close to each other in magnitude and thus prone to permute, whereas $0.5<\varphi \leq 1$ indicates possible permutations between $\sigma_{1}$ and $\sigma_{2}$ [Angelier, 1994]. Low $\varphi$ values were obtained for the two extensional paleostress tensors ( 0.2 on average), indicating that the magnitudes of $\sigma_{2}$ and $\sigma_{3}$ were close to each other and 

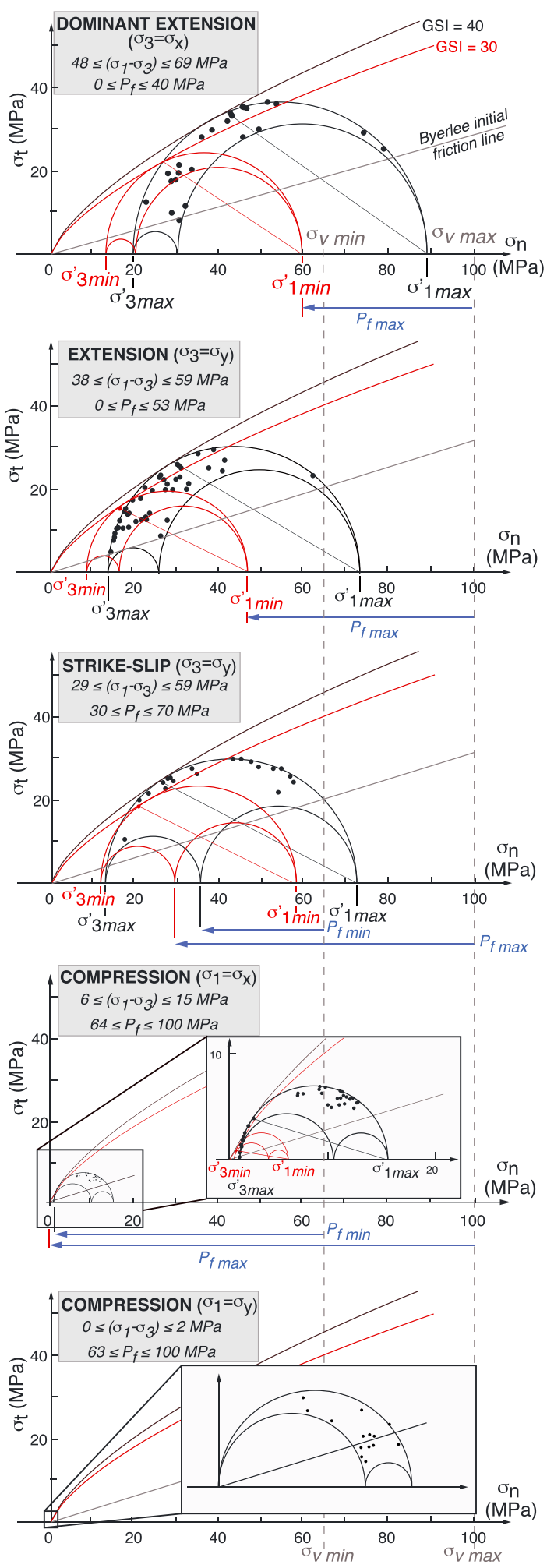

Figure 13. Quantification of paleostress effective magnitudes $\sigma_{1}^{\prime}, \sigma_{2}^{\prime}$, and $\sigma_{3}^{\prime}$ for each stress regime at the site SZ2, using dimensional Mohr circle constructions ( $\sigma_{t}$ : tangential stress, $\sigma_{n}$ : normal stress). Black dots represent fault-slip and extension fracture data, and $P_{f}$ is the estimated range of pore fluid pressure values. The maximum (black) and minimum (red) failure envelopes are plotted using the Hoek et al. [2002] failure criterion, with parameter values adapted to the petrological and textural characteristics of sills: Geological Strength Index (GSI) $=40$ (black curve) to 30 (red curve), material constant for the intact rock $m_{i}=25$, and uniaxial compressive strength for the intact rock $\sigma_{\mathrm{ci}}=100 \mathrm{MPa}$ (values from Schultz [1995], Hoek and Brown [1997], and Apuani et al. [2005]). The initial friction line is plotted with a friction angle of 16.7 [Byerlee, 1978]. Black and red Mohr circles thus correspond to the maximum and minimum possible deviatoric stresses $\left(\sigma_{1}-\sigma_{3}\right)$ fitting these rock failure criteria. 
their axes were prone to permute. Similarly, the high values ( 0.75 on average) obtained for all the compressional tensors indicate that $\sigma_{1}$ and $\sigma_{2}$ were close to each other and that their axes were also able to switch. Our strike-slip tensors have intermediate $\varphi$ values $(0.4 \leq \varphi \leq 0.7)$ and thus do not match this interpretation, probably because these tensors are in practice calculated from an average of fault-slip data coming from extension-strike-slip permutations (at $\varphi<0.5$ ) and compression-strike-slip permutations (at $\varphi>0.5$ ).

The third mechanical consequence of the model of Vigneresse et al. [1999] is that the increasing number of intrusions reduces the deviatoric stress $\left(\sigma_{1}-\sigma_{3}\right)$ at each permutation and eventually leads to a nearly isotropic stress field $\left(\sigma_{1}=\sigma_{2}=\sigma_{3}\right)$. The progressive reduction of the deviatoric stress firstly tends to prevent fault neoformation as the Coulomb failure criterion is no longer satisfied and then to reduce the occurrence of reactivated faults. In Salazie, normal, strike-slip, and thrust faults account for 461, 84, and 64 of the measured tectonic structures, respectively (Table 1), in agreement with a reduction of the deviator from extension to compression. As illustrated by Figure 13, this reduction of the deviatoric stress has been quantified in the example of the Mât river sill zone (site SZ2), using three conditions: (1) Neoformed faults and extension fractures plotted on a Mohr diagram must be tangential to the failure envelope of rocks (determined using the rock strength analysis of Hoek et al. [2002]); (2) reactivated faults must lie above the initial friction line of rocks (using the friction angle of $16.7^{\circ}$ and the zero cohesion of Byerlee [1978]); and (3) the vertical effective stress cannot exceed the lithostatic stress estimated at 65-100 MPa (i.e., 2500-3200 m). These conditions impose a deviatoric stress of 48-69 MPa for the dominant NNE-SSW extension, 38-59 MPa for the secondary extension, 29-59 MPa for the strike-slip regime, and 0-15 MPa for the compressions. Note also that neoformed faults decrease in proportion with reactivated faults from the extensional to the strike-slip regimes and disappear in the compressional stress regime (Figure 13). These results match our proposed scenario of stress permutations and deviator reduction by repeated injections in the volcano.

Strictly speaking, however, neoformed faults should be found only in the dominant extension, unless the pore fluid pressure was nonzero and varied from one stress tensor to the next. This was clearly the case for the compressions at site SZ2, where the occurrence of subhorizontal serpentine-filled extension fractures (Figure 2e) implies the existence of a pore fluid pressure equal to the lithostatic load $\left(\sigma_{v}=\sigma_{3}\right)$. Similarly, the observation of mineralized extension fractures at other sites (Pah14 and Bb1) suggests that the pore fluid pressure was transiently equal to the minimum principal stress. These fluctuations of the pore fluid pressure may have been caused by the transient heat of intrusions.

\subsection{Restoration of Stress Permutation Cycles}

Because the final stress state after sill injections should be nearly isotropic according to the model of Vigneresse et al. [1999], an additional mechanism is required to restore the stress field into its initial, extensional state. Famin and Michon [2010] showed that sill zones localize ductile and brittle shear deformation between (and also perhaps during) the magma injections, leading to the formation of the detachment. Because the sills are gently sloping outward (i.e., toward the sea), this shear deformation results in a collapse of the flanks of the edifice that may restore the extensional stress field by lowering the lateral confinement. The shear deformation induced by sill injection is thus able to start a new cycle of stress permutations (Figure 12). Repeated over a long period of time, this succession of extensions, strike-slip, thrusting, and slip on sill surfaces would explain the overlap of incompatible orientations of deformation and intrusions observed at Piton des Neiges.

\subsection{Stress Permutations at Piton de la Fournaise Volcano}

From the distribution of minor eruptive vents, two curved and diffuse rift zones may be defined at Piton de la Fournaise, the active volcano of La Réunion (Figure 14). Most of the eruptions occur inside the Enclos Fouqué caldera and may be classified into three categories. The first category, encompassing the majority of eruptions (16 eruptions since February 1981), comprises N25-30E eruptive fissures along the NE rift zone (Figure 14) and in the vicinity of the summit cone [Michon et al., 2009]. The erupted products are essentially aphyric basalts ( 5$8 \mathrm{wt} \% \mathrm{MgO}$ ). The second, less frequently observed category (seven eruptions since February 1981), comprises eruptive fissures oriented $\mathrm{N} 120^{\circ} \mathrm{E}$, also in the vicinity of the summit cone [Michon et al., 2009], and usually emitting lavas with a moderate amount of olivine ( 7-9 wt \% MgO). The junction of the two first categories of eruptive fissures is located on the southwestern side of the Dolomieu crater [Michon et al., 2007, 2009]. Numerical modeling of coeruptive deformation sources showed that the feeder intrusions of these two 


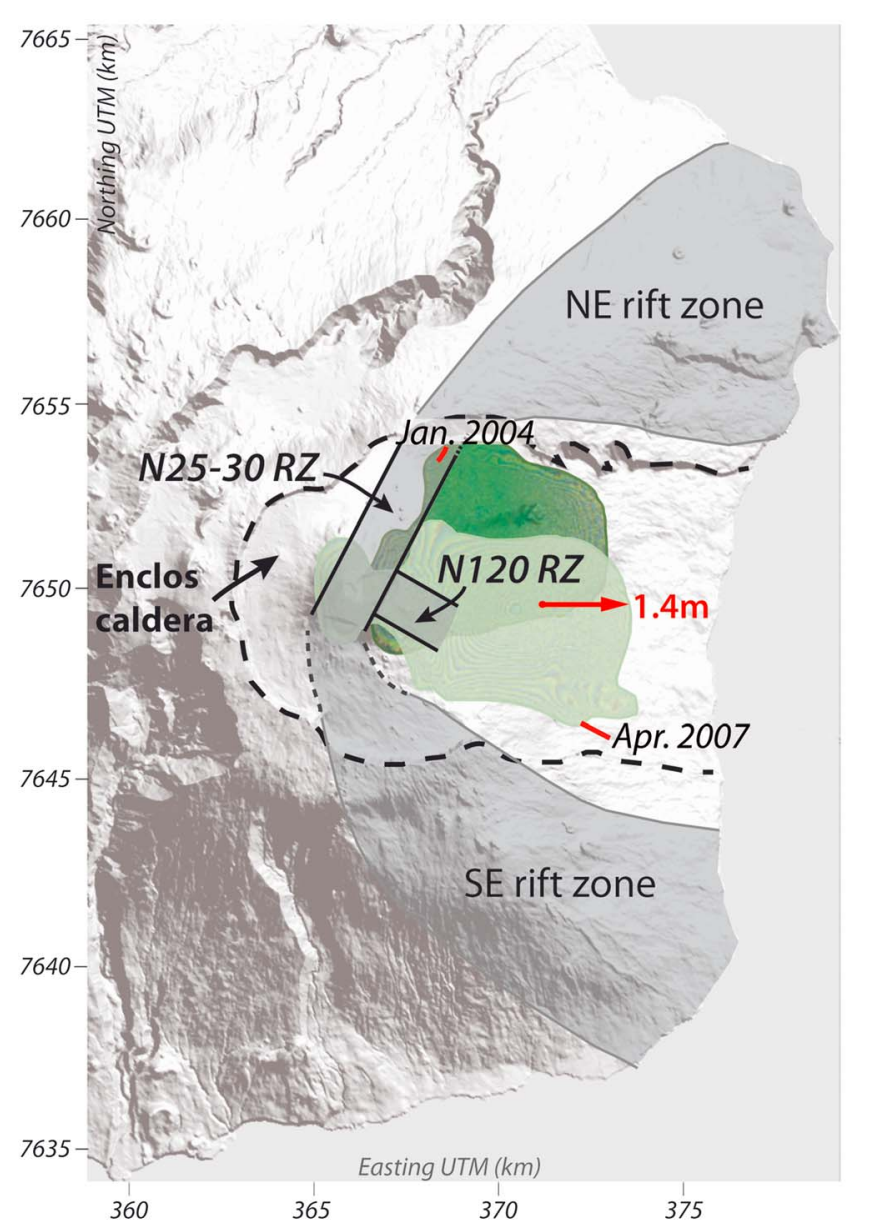

Figure 14. Magmatic activity and deformation of Piton de la Fournaise. Rift zones (RZ) are defined from the location and orientation of eruptive vents and fissures. Red lines are the eruptive fissures of January 2004 and April 2007 eruptions. The dark green and light green zones represent the areas of cointrusive horizontal displacement during the January 2004 and April 2007 eruptions taken from Tinard [2007], Froger et al. [2010], and Augier [2011]. The red arrow indicates the area of maximum coeruptive horizontal displacement (1.4 $\mathrm{m}$ ) during the April 2007 eruption. Map coordinates are in UTM (km) WGS 84.

categories of eruptions are subvertical dikes [Froger et al., 2004; Peltier et al., 2005, 2008; Fukushima et al., 2010]. The third category comprises infrequent eruptions on the lower eastern slopes of the volcano and far from the summit cone, such as in January 2004, February 2005, December 2005, and April 2007 (Figure 14). The magmas emitted during these eruptions are olivine-rich basalts ( 10-29 wt \% MgO). The proposed explanation for this enrichment in olivine is that eruptions of the third category stem from lower zones in the reservoir and hence are composed of more crystal-rich magmas than the two other categories [Peltier et al., 2008; Famin et al., 2009]. This suggests that the summit dikes would have originated from subvertical fractures in the roof of the magma reservoir, which are favored in extensional or strike-slip stress fields, whereas the distal eruptions would stem from subhorizontal fractures in the lateral walls, more likely to occur in a compressional stress field as sills [Got et al., 2013]. The pattern of coeruptive surface displacements during the January 2004 and April 2007 eruptions could also be consistent with sill intrusions, as proposed by Tinard [2007] and confirmed by Augier [2011] for April 2007. The January 2004 and April 2007 eruptions were also characterized by large horizontal displacements of the eastern flank of the volcano toward the east (up to $1.4 \mathrm{~m}$ in $1 \mathrm{month}$, Figure 14), suggesting the existence of a detachment activated in eruptive periods [Froger et al., 2010; Augier, 2011]. The motion of the fault continued long after the April 2007 eruption, as evidenced by posteruptive interferometric synthetic aperture radar interferograms and by the GPS stations installed in April 2010 (3.4 cm.yr ${ }^{-1}$ eastward displacement rate) [Brenguier et al., 2012]. In summary, the three categories of eruptions therefore comprise three injection orientations perpendicular to each other: two dike trends and likely one sill trend, the latter being sometimes associated with coeruptive and posteruptive detachment slip. Note that the eruptions of Piton de la Fournaise 

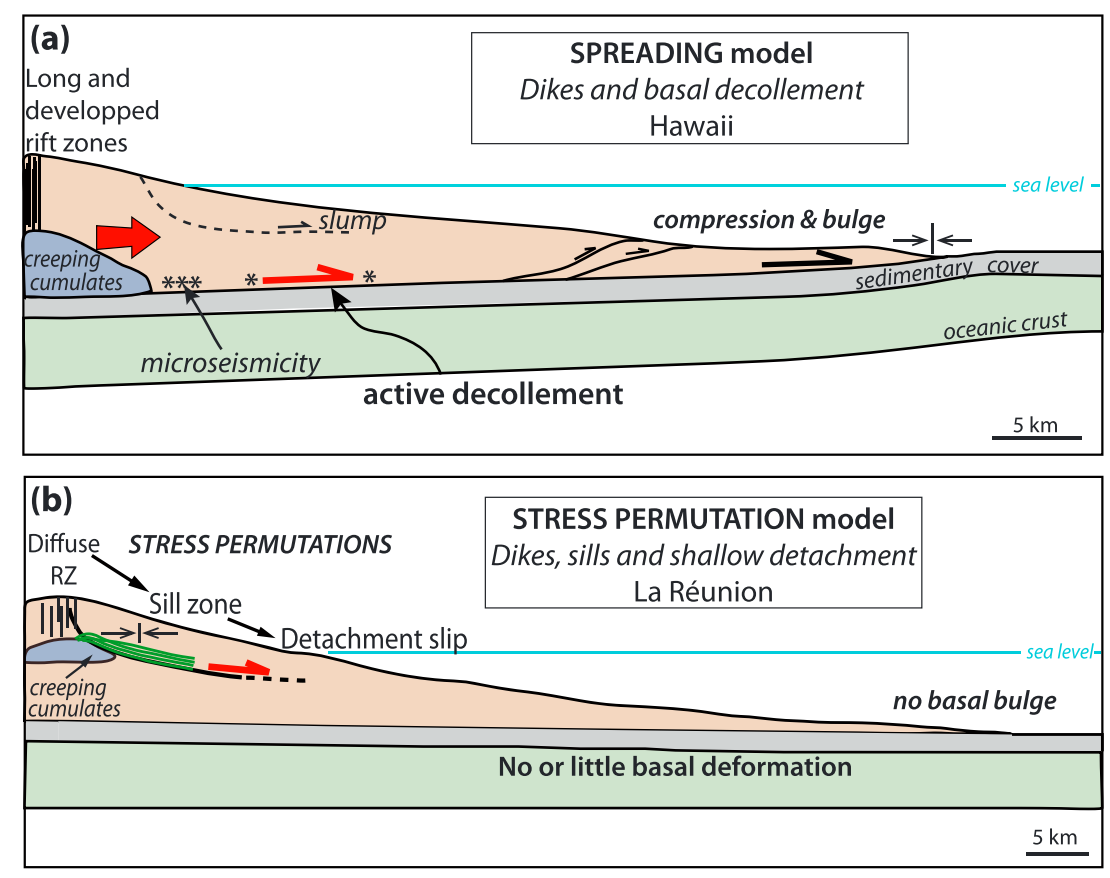

Figure 15. Sketches highlighting the differences in deformation and magmatic activity between Hawaiian and Réunion-like volcanoes. (a) The spreading model of Hawaiian volcanoes: a décollement, possibly activated by creeping cumulates, very active and persistent rift zones, and compression at the base of the edifice. (b) The stress permutation model of Réunion-like volcanoes: no basal creep, smaller magmatic system, intrusions alternatively captured into sill zones and diffuse rift zones (RZ), and intermittent compression in the upper part of the edifice.

interpreted as sills are similar in terms of lava composition to the average composition of the sills observed at Piton des Neiges (olivine-rich basalts). The coeruptive and posteruptive slips of the detachment at Piton de la Fournaise are also consistent with the brittle and ductile shear deformation structures observed in the Piton des Neiges detachment [Famin and Michon, 2010]. In addition, comparison of Figures 11 and 14 shows that the repartition of rift zones, sill zones, and highly deformed zones is strikingly similar on the two volcanoes. There is thus a strong analogy between Piton des Neiges and Piton de la Fournaise, which suggests that stress permutations may also occur in the latter volcano. During the 2000-2007 period, eruptions at Piton de la Fournaise were organized as cycles, each beginning by a N25-30 rift zone eruption (e.g., August 2006) and ending by a distal eruption that can be associated with seaward slip (e.g., April 2007). The duration of these eruptive cycles ranged between 8 months (e.g., from May 2003 to January 2004) and 2 years (e.g., from February 2000 to January 2002). These switches of eruptive pattern suggest that the stress permutation cycles depended on the eruption rate and lasted a few years at Piton de la Fournaise.

\subsection{Do Stress Permutations Occur on Other Basaltic Volcanoes?}

In Tenerife (Canary Islands), the lithosphere is flexured and suggests an influence of sagging [Fernández et al., 2009], but no compressional structures typically associated with this deformation process have been observed. Some authors have proposed that the deformation of Tenerife proceeds by spreading on a décollement [e.g., Walter, 2003; Delcamp et al., 2012], yet no evidence of a décollement has been either found [Collier and Watts, 2001; Fernández et al., 2009]. Marinoni and Gudmundsson [2000] reported the synchronous occurrence of two perpendicular dike orientations and two perpendicular directions of normal faulting. These authors explained their results as recurrent stress permutations between a dominant NE-SW extension (imposed by the regional tectonics) and a secondary WNW-ESE extension in Tenerife. On several other Canarian volcanoes (e.g., La Palma, La Gomera), no evidence of spreading is found either [Carracedo, 1999; Mitchell et al., 2002], while sill zones, perpendicular dike trends (sometimes with detachments), and perpendicular paleostress orientations have been extensively described [Cendrero, 1970; Staudigel and Schmincke, 1984; Staudigel et al., 1986; Ahijado et al., 2001; Fernández et al., 2002, 2006; Ancochea et al., 2008; Geyer and Martì, 2010]. These features were most often interpreted as being caused 
by successive periods of tectonic and/or volcanic activity. It is, however, possible that some of these features may be due to intrusion-related stress permutations, but further work is needed to verify this hypothesis.

Byrne et al. [2013] proposed that deformation at Big Island (Hawaii) and La Réunion is dominated by gravitational spreading (despite the important lithospheric flexure under Hawaii). However, many differences are observed in the volcano-tectonic architecture of both edifices that cannot be explained by the model of Byrne et al. [2013]. Our model of stress permutations explains several of these discrepancies between Hawaiian and Réunion-like volcanoes (Figure 15). One of them is the shape of the rift zones. Long and narrow Hawaiian rift zones are very active and capture thousands of subvertical dikes [Pollard et al., 1983; Dieterich, 1988] because $\sigma_{3}$ retains the same orientation with time, maintained by slip on a basal décollement at the interface between the volcanic pile and the oceanic plate [Got et al., 1994; Denlinger and Okubo, 1995; Morgan et al., 2000, 2003]. On the other hand, in La Réunion and on similar volcanoes, intrusions are split into three sets due to stress permutations, explaining why rift zones are so diffuse and weakly defined when compared to Hawaii. Another fundamental difference is the spreading behavior of the edifices. In the case of Hawaii, the single orientation of $\sigma_{3}$ implies that the slip of the décollement plane persistently compensates dike injections in the rift zones and normal faulting, i.e., the spreading rate is equal to or greater than the intrusion rate. In Réunion-like volcanoes, on the contrary, the reduction of the deviatoric stress, a necessary condition for each cycle of stress permutations to occur, implies that the basal creep of the edifice, if any, does not compensate the increase of the two smaller principal stresses caused by magma injections. In other words, the intrusion rate in the edifice must be greater than the deformation rate at the base of the edifice. Even with a magma supply rate similar to that in Hawaii, Réunion-like volcanoes would be therefore expected to undergo smaller basal creep. Given that the magma supply rate in La Réunion $\left(0.02 \mathrm{~km}^{3} . \mathrm{yr}^{-1}\right)$ [Peltier, 2007] is about one tenth of that in Hawaii $\left(0.19 \mathrm{~km}^{3}\right.$. $\mathrm{yr}^{-1}$ ) [Cayol et al., 2000], deformation at the base of the edifice must be very limited. Offshore surveys have revealed a moderate amount of deformation on the northeastern side of Piton des Neiges (i.e., offshore of the $\mathrm{N} 020^{\circ} \mathrm{E}$ extension found in this study) and no significant deformation at the base of Piton de la Fournaise [Le Friant et al., 2011]. We thus suggest that spreading on these volcanoes is dominated by slip on shallow detachments, slumps, and episodic landslides rather than basal creep. These are also the modes of spreading proposed for the Canary Islands [Carracedo, 1999; Mitchell et al., 2002; Morgan and McGovern, 2005]. The spreading of the Kilauea in Hawaii is thought to result from the creep of dunites accumulated by magma differentiation [Clague and Denlinger, 1994]. A possible cause of the absence of creep in La Réunion could be the much smaller size of its magmatic system in general and of its creeping cumulates in particular. For basaltic volcanoes with similar magma supply rates, the recurrent stress permutations and limited creep of La Réunion could stand as a more adequate model of volcano deformation than the spreading of Hawaiian volcanoes.

\section{Conclusion}

Our study of sheet intrusions and deformation microstructures of Piton des Neiges reveals that recurrent switches in intrusion trends and in principal stress axes occurred during the life of the volcano. Sheet intrusions display three perpendicular populations that coexisted in time: a main population of subvertical dikes oriented NNE-SSW, a secondary trend of subvertical dikes ESE-WNW, and a third population of subhorizontal sills. The spatial repartition of intrusions suggests the existence of a diffuse $\mathrm{N} 120-140^{\circ} \mathrm{E}$ rift zone and at least two sill zones with a very high concentration of intrusions. Consistent with the intrusion data, the inversion of fault-slip data revealed that incompatible deformation regimes coexisted during the time period of magma injections: a dominant extension in the direction NNE-SSW, a secondary perpendicular extension ESE-WNW, and strike-slip or thrust faulting regimes in the vicinity of the rift zone and the sill zones. Given the agreement between intrusion and fault-slip data, we propose that cycles of stress permutations occurred recurrently at Piton des Neiges as a consequence of repeated magma injections. Each cycle of permutations resulted in a progressive evolution of the stress field, due to accumulated dike intrusions, from extension to strike slip and compression, ending up with the injection of sills. At the end of each cycle, slip on the sill zones eventually restored the extensional stress field, initiating a new cycle of dike intrusions and stress permutations. Our model of stress permutations by magma injections is consistent with the behavior of Piton de la Fournaise, where three injection orientations, two dike trends, and one sill trend appear to have occurred. Recent eruptions attributed to sill injections, such as the April 2007 eruption, also resulted in the slip of the volcano on a detachment plane. The recognition of stress permutations implies that basal deformation is not sufficient to maintain a constant stress field in the edifice and hence suggests the absence of significant basal creep. Our model of stress permutations and slip on the sill zones, based 
on field observations, constitutes an alternative to the Hawaiian model of spreading on a décollement, applicable to basaltic volcanoes where sill zones are observed and spreading by basal creep is not.

\section{Appendix A: Effect of Dike Intrusion Under Plane Strain Field}

For an isotropic linear elastic medium, the generalized Hooke's law takes the following form:

$$
\begin{aligned}
& \varepsilon_{x}=\frac{1}{E}\left[(1+v) \sigma_{x}-v\left(\sigma_{x}+\sigma_{y}+\sigma_{z}\right)\right] \\
& \varepsilon_{y}=\frac{1}{E}\left[(1+v) \sigma_{y}-v\left(\sigma_{x}+\sigma_{y}+\sigma_{z}\right)\right] \\
& \varepsilon_{z}=\frac{1}{E}\left[(1+v) \sigma_{z}-v\left(\sigma_{x}+\sigma_{y}+\sigma_{z}\right)\right]
\end{aligned}
$$

where $\varepsilon$ is the strain, $\sigma$ the stress, $E$ the Young's modulus, and $v$ the Poisson's ratio.

Let us consider an extensional stress regime with $\sigma_{3}, \sigma_{2}$, and $\sigma_{1}$ oriented along the $x, y$, and $z$ axes, respectively, and where dikes will emplace perpendicular to $\sigma_{x}$ (i.e., $\sigma_{3}$ ) according to Anderson's theory. Under plane strain field, the deformation is thus considered as null parallel to the $y$ axis so that

$$
\varepsilon_{y}=0
$$

Substituting this condition in equation (A2)

$$
\sigma_{y}-v\left(\sigma_{x}+\sigma_{z}\right)=0
$$

and thus,

$$
\sigma_{y}=v\left(\sigma_{x}+\sigma_{z}\right)
$$

After dike intrusion at a magma pressure $P$, the stress along the $x$ axis $\sigma_{x}^{\prime}$ is increased of a value of $P$. The stress along the $z$ axis $\sigma_{z}^{\prime}$ remains unchanged since the edifice is not vertically constrained

$$
\begin{gathered}
\sigma_{x}^{\prime}=\sigma_{x}+P \\
\sigma_{z}^{\prime}=\sigma_{z}
\end{gathered}
$$

According to equation (A6), the stress along the $y$ axis $\sigma_{y}^{\prime}$ after intrusion emplacement is

$$
\sigma_{y}^{\prime}=v\left(\sigma_{x}^{\prime}+\sigma_{z}^{\prime}\right)
$$

Substituting $\sigma_{x}^{\prime}$ and $\sigma_{z}^{\prime}$ from the equations (A7) and (A8):

$$
\begin{aligned}
& \sigma_{y}^{\prime}=v\left(\sigma_{x}+P+\sigma_{z}\right) \\
& \sigma_{y}^{\prime}=v\left(\sigma_{x}+\sigma_{z}\right)+v P
\end{aligned}
$$

and then

Acknowledgments

We thank C. Berthod and S. Garcia for their participation in the fieldwork. RicaRic is thanked for organizing the exploration of the upper part of Piton des Neiges. The Ph.D. fellowship of M. Chaput is funded by the French Ministère de la Recherche et de l'Enseignement supérieur. This research has been supported by INSU-CNRS grants. This is IPGP contribution 3479. The authors thank $\mathrm{O}$. Lacombe, $\mathrm{C}$. Fernandez, and two anonymous reviewers for their helpful reviews.

$$
\sigma_{y}^{\prime}=\sigma_{y}+v P
$$

After dike intrusion in an extensional regime, the stress along the $y$ axis (i.e., the intermediate stress $\sigma_{2}$ ) has thus been increased of a value of $v P$.

\section{References}

Ahijado, A., R. Casillas, and A. Hernández-Pacheco (2001), The dyke swarms of the Amanay Massif, Fuerteventura, Canary Islands (Spain), J. Asian Earth Sci, 19(3), 333-345, doi:10.1016/s1367-9120(99)00066-8.

Aki, K., and P. G. Richards (2002), Quantitative Seismology: Theory and Methods, 2nd ed., pp. 703, University Science Books, Sausalito, Calif. Ancochea, E., J. L. Brändle, M. J. Huertas, F. Hernán, and R. Herrera (2008), Dike-swarms, key to the reconstruction of major volcanic edifices: The basic dikes of La Gomera (Canary Islands), J. Volcanol. Geotherm. Res., 173(3-4), 207-216, doi:10.1016/j.jvolgeores.2008.01.020. 
Angelier, J. (1975), Sur l'analyse de mesures recueillies dans des sites faillés: L'utilité d'une confrontation entre les méthodes dynamiques et cinématiques, C.R. Acad. Sci. Paris, Serie D, 281, 1805-1808.

Angelier, J. (1984), Tectonic analysis of fault slip data sets, J. Geophys. Res., 89(B7), 5835-5848.

Angelier, J. (1994), Fault slip analysis and paleostress reconstruction, in Continental Deformation, edited by P. L. Hancock, pp. 53-100, Pergamon Press, Oxford, U. K.

Anguita, F., L. Garcia Cacho, F. Colombo, A. Gonzalez Camacho, and R. Vieira (1991), Roque Nublo caldera: A new stratocone caldera in Gran Canaria, Canary Islands, J. Volcanol. Geotherm. Res., 47(1-2), 45-63.

Apuani, T., C. Corazzato, A. Cancelli, and A. Tibaldi (2005), Physical and mechanical properties of rock masses at Stromboli: A dataset for volcano instability evaluation, Bull. Enginnering Geol. and Env., 64(4), 419-431, doi:10.1007/s10064-005-0007-0.

Arnaud, N. (2005), Les processus de démantèlement des volcans, la cas d'un volcan bouclier en milieu océanique: Le Piton des Neiges (Ile de la Réunion), PhD thesis, Lab. Sc. Terre Univers Reunion, Université de la Réunion, France.

Augier, A. (2011), Etude de l'éruption d'avril 2007 du Piton de la Fournaise (île de la Réunion) à partir de données d'interférométrie radar et GPS, développement et application de procédures de modélisation, PhD thesis, Lab. Magmas et Volcans, Université Blaise Pascal, Clermont-Ferrand, France.

Bachèlery, P., B. Robineau, M. Courteaud, and C. Savin (2003), Avalanches de débris sur le flanc occidental du volcan-bouclier Piton des Neiges (Réunion), Bull. Soc. Geol. Fr., 174(2), 125-140.

Birch, F. (1961), The velocity of compresional waves in rocks to 10 kilobars, Part 2, J. Geophys. Res., 66, $2199-2224$.

Borgia, A. (1994), Dynamics of volcanic spreading, J. Geophys. Res., 99(B9), 17,791-17,804.

Bott, M. H. P. (1959), The mechanics of oblique slip faulting, Geol. Mag., 96, 109-117.

Brenguier, F., et al. (2012), First Results from the UnderVolc High Resolution Seismic and GPS Network Deployed on Piton de la Fournaise Volcano, Seism. Res. Lett., 83(1), 97-102, doi:10.1785/gssrl.83.1.97.

Bret, L., Y. Fèvre, J.-L. Join, B. Robineau, and P. Bachèlery (2003), Deposits related to degradation processes on Piton des Neiges Volcano (Reunion Island): Overview and geological hazard, J. Volcanol. Geotherm. Res., 123(1-2), 25-41, doi:10.1016/s0377-0273(03)00026-x.

Brooks, B. A., J. Foster, D. Sandwell, C. J. Wolfe, P. Okubo, M. P. Poland, and D. Myer (2008), Magmatically triggered slow slip at Kilauea volcano, Hawaii, Science, 321, 1177.

Burchardt, S. (2008), New insights into the mechanics of sill emplacement provided by field observation of the Njardvik Sill, Northeast Iceland, J. Volcanol. Geotherm. Res., 173(3-4), 280-288, doi:10.1016/j.jvolgeores.2008.02.009.

Byerlee, J. (1978), Friction of rocks, Pure Appl. Geophys., 116, 615-626.

Byrne, P. K., E. P. Holohan, M. Kervyn, B. van Wyk de Vries, V. R. Troll, and J. B. Murray (2013), A sagging-spreading continuum of large volcano structure, Geology, 41(3), 339-342, doi:10.1130/G33990.1.

Carracedo, J. C. (1999), Growth, structure, instability and collapse of Canarian volcanoes and comparisons with Hawaiian volcanoes, J. Volcanol. Geotherm. Res., 94(1-4), 1-19, doi:10.1016/s0377-0273(99)00095-5.

Cayol, V., and F. H. Cornet (1998), Three-dimensional modeling of the 1983-1984 eruption at Piton de la Fournaise volcano, Réunion Island, J. Geophys. Res., 103, 18,025-18,037.

Cayol, V., J. H. Dieterich, A. T. Okamura, and A. Miklius (2000), High magma storage rates before the 1983 eruption of Kilauea, Hawaii, Science, 288, 2343-2345.

Cecchi, E., B. van Wyk de Vries, and J.-M. Lavest (2005), Flank spreading and collapse of weak-cored volcanoes, Bull. Volc., 67, 72-91, doi:10.1007/s00445-004-0369-3.

Cendrero, A. (1970), The Volcano-plutonic Complex of La Gomera (Canary Islands), Bull. Volcanol., 34, 537-561.

Chadwick, W. W., and J. H. Dieterich (1995), Mechanical modeling of circumferential and radial dike intrusion on Galapagos volcanoes, J. Volcanol. Geotherm. Res., 66, 37-52.

Chevallier, L., and N. Vatin-Pérignon (1982), Volcano-structural evolution of Piton des Neiges, Reunion Island, Indian Ocean, Bull. Volcanol., 45, 285-298.

Clague, D. A., and R. P. Denlinger (1994), Role of olivine cumulates in destabilizing the flanks of Hawaiian volcanoes, Bull. Volcanol., 56, 425-434.

Collier, J. S., and A. B. Watts (2001), Lithospheric response to volcanic loading by the Canary Islands: Constraints from seismic reflection data in their flexural moat, Geophys. J. Int., 147, 660-676.

Day, S. J., J. C. Carracedo, H. Guillou, and P. Gravestock (1999), Recent structural evolution of the Cumbre Vieja volcano, La Palma, Canary Islands: Volcanic rift zone reconfigurationn as a precursor to volcano flank instability, J. Volcanol. Geotherm. Res., 94, $135-167$.

Delaney, P. T., D. D. Pollard, J. I. Ziony, and E. H. McKee (1986), Field relations between dikes and joints: Emplacement processes and paleostress analysis, J. Geophys. Res., 91, 4220-4938.

Delcamp, A., V. R. Troll, B. van Wyk de Vries, J. C. Carracedo, M. S. Petronis, F. J. Pérez-Torrado, and F. M. Deegan (2012), Dykes and structures of the NE rift of Tenerife, Canary Islands: A record of stabilisation and destabilisation of oceanic rift zones, Bull. Volcanol., 74(5), 963-980, doi:10.1007/s00445-012-0577-1.

Delvaux, D., and B. Sperner (2003), New aspect of tectonic stress inversion with reference to the TENSOR program, in New Insights Into Structural Interpretation and Modelling, edited by D. A. Nieuwland, pp. 75-100, Geological Society, Special Publications, London, U. K.

Demange, J., P. Chovelon, and P. Puvilland (1989), Geothermal model of the Salazie Cirque (Reunion Island): Volcanic and structural implications, J. Volcanol. Geotherm. Res., 36(1-3), 153-176, doi:10.1016/0377-0273(89)90011-5.

Denlinger, R. P., and P. Okubo (1995), Structure of the mobile south flank of Kilauea volcano, Hawaii, J. Geophys. Res., 100(B12), $24,499-24,507$.

de Voogd, B., S. Pou Palomé, A. Hirn, P. Charvis, J. Gallart, D. Rousset, J. Dañobeitia, and H. Perroud (1999), Vertical movements and material transport during hotspot activity: Seismic reflection profiling offshore La Réunion, J. Geophys. Res., 104(B2), 2855-2874, doi:10.1029/ 98JB02842.

Dieterich, J. H. (1988), Growth and persistence of Hawaiian Volcanic Rift Zones, J. Geophys. Res., 93(B5), 4258-4270.

Dyment, J. (1991), Analyse de la subsidence et données sismiques profondes: Implications géodynamiques sur la formation et l'évolution des bassins celtiques, in Etude de la Croûte Terrestre par Sismique Profonde: Mer Celtique-Manche et ses Approches Occidentales; profils SWAT et WAM, vol. 159, edited by C. Bois, J. C. Sibuet, and O. Gariel, pp. 67-81, Societe Geologique de France, Paris, France.

Famin, V., and L. Michon (2010), Volcano destabilization by magma injections in a detachment, Geology, 38(3), 219-222, doi:10.1130/g30717.1.

Famin, V., B. Welsch, S. Okumura, P. Bachèlery, and S. Nakashima (2009), Three differentiation stages of a single magma at Piton de la Fournaise volcano (Reunion hot spot), Geochem. Geophys. Geosyst., 10, Q01007, doi:10.1029/2008gc002015. 
Fernández, C., J. De la Nuez, and R. Casillas (2002), Stress field associated with the growth of a large shield volcano (La Palma, Canary Islands), Tectonics, 21(41031), doi:10.1029/2000TC900038.

Fernández, C., R. Casillas, E. García Navarro, M. Gutiérrez, M. A. Camacho, and A. Ahijado (2006), Miocene rifting of Fuerteventura (Canary Islands), Tectonics, 25, TC6005, doi:10.1029/2005TC001941.

Fernández, J., et al. (2009), Gravity driven deformation of Tenerife measured by InSAR time series analysis, Geophys. Res. Lett., 36 L04306, doi:10.1029/2008GL036920.

Froger, J.-L., Y. Fukushima, P. Briole, T. Staudacher, T. Souriot, and N. Villeneuve (2004), The deformation fiel of the August 2003 eruption at Piton de la Fournaise, Reunion Island, mapped by ASAR interferometry, Geophys. Res. Lett., 31 L14601, doi:10.1029/2004GL020479.

Froger, J.-L., A. Augier, V. Cayol, and T. Souriot (2010), Some considerations about the April 2007 eruption at Piton de la Fournaise suggested by InSAR data, paper presented at 4th Collapse Caldera Workshop, IAVCEI, La Réunion Island, France.

Fukushima, Y., V. Cayol, P. Durand, and D. Massonnet (2010), Evolution of magma conduits during the 1998-2000 eruptions of Piton de la Fournaise volcano, Réunion Island, J. Geophys. Res., 115 B10204, doi:10.1029/2009JB007023.

Gailler, L.-S., and J.-F. Lénat (2012), Internal architecture of La Réunion (Indian Ocean) inferred from geophysical data, J. Volcanol. Geotherm. Res., 221-222, 83-98, doi:10.1016/j.jvolgeores.2012.01.015.

Galindo, I., C. Soriano, J. Martì, and N. Pérez (2005), Graben structure in the Las Cañadas edifice (Tenerife, Canary Islands): Implications for active degassing and insights on the caldera formation, J. Volcanol. Geotherm. Res., 144(1-4), 73-87, doi:10.1016/j.jvolgeores.2004.11.017.

Gapais, D., P. R. Cobbold, O. Bourgeois, D. Rouby, and M. de Urreiztieta (2000), Tectonic significance of fault-slip data, J. Struct. Geol., 22(7), 881-888.

Geoffroy, L., F. Bergerat, and J. Angelier (1993), Modification d'un champ de contrainte régional par un champ de contraintes magmatiques local. Exemple de l'île de Skye (Ecosse) au Paléocène, Bull. Soc. Geol. Fr., 164(4), 541-552.

Geyer, A., and J. Martì (2010), The distribution of basaltic volcanism on Tenerife, Canary Islands: Implications on the origin and dynamics of the rift systems, Tectonophysics, 483(3-4), 310-326, doi:10.1016/j.tecto.2009.11.002.

Gillot, P. Y., and P. Nativel (1982), K-Ar chronology of the ultimate activity of piton des neiges volcano, reunion island, Indian ocean, J. Volcanol. Geotherm. Res., 13(1-2), 131-146.

González, P. J., K. F. Tiampo, A. G. Camacho, and J. Fernández (2010), Shallow flank deformation at Cumbre Vieja volcano (Canary islands): Implications on the stability of stee-sided volcano flanks at oceanic islands, Earth Planet. Sci. Lett., 297(3-4), 545-557, doi:10.1016/j. epsl.2010.07.006.

Got, J.-L., J. Fréchet, and F. W. Klein (1994), Deep fault plane geometry inferred from multiplet relative relocation beneath the south flank of Kilauea, J. Geophys. Res., 99(B8), 15,375-15,386, doi:10.1029/94JB00577.

Got, J.-L., A. Peltier, T. Staudacher, P. Kowalski, and P. Boissier (2013), Edifice strength and magma transfer modulation at Piton de la Fournaise volcano, J. Geophys. Res. Solid Earth, 118, 5040-5057, doi:10.1002/jgrb.50350.

Gudmundsson, A. (2005), The effect of layering and local stresses in composite volcanoes on dyke emplacement and volcanic hazards, C. $R$. Geosci., 337(13), 1216-1222, doi:10.1016/j.crte.2005.07.001.

Gudmundsson, A. (2006), How local stresses control magma-chamber ruptures, dyke injections, and eruptions in composite volcanoes, Earth Sci. Rev., 79(1-2), 1-31, doi:10.1016/j.earscirev.2006.06.006.

Gudmundsson, A. (2011), Deflection of dykes into sills at discontinuities and magma-chamber formation, Tectonophysics, 500(1-4), 50-64, doi:10.1016/j.tecto.2009.10.015.

Gudmundsson, A., and I. Loetveit (2005), Dyke emplacement in a layered and faulted rift zone, J. Volcanol. Geotherm. Res., 144(1-4), 311-327, doi:10.1016/j.jvolgeores.2004.11.027.

Hoek, E., and E. T. Brown (1997), Practical estimates of rock mass strength, Int. J. Rock Mechanics and Mining Sci., 34(8), $1165-1186$.

Hoek, E., C. T. Carranza-Torres, and B. Corkum (2002), Hoek-Brown failure criterion - 2002 Edition, paper presented at TAC Conference, North American Rock Mechanics Society, Toronto, Canada.

$\mathrm{Hu}$, J.-C., and J. Angelier (2004), Stress permutations: Three-dimensional distinct element analysis accounts for a common phenomenon in brittle tectonics, J. Geophys. Res., 109, B09403, doi:10.1029/2003JB002616.

Jaeger, J. C., N. G. Cook, and R. Zimmerman (2007), Fundamentals of Rock Mechanics, 4th ed., pp. 469, Blackwell Publishing Ltd, Malden, USA.

Kavanagh, J. L., T. Menand, and R. S. J. Sparks (2006), An experimental investigation of sill formation and propagation in layered elastic media, Earth Planet. Sci. Lett., 245(3-4), 799-813, doi:10.1016/j.epsl.2006.03.025.

Kaven, J. O., M. Maerten, and D. D. Pollard (2011), Mechanical analysis of fault slip data: implications for paleostress analysis, J. Struct. Geol., 33(2), 78-91.

Kluska, J.-M. (1997), Evolution magmatique et morpho-structurale du Piton des Neiges au cours des derniers 500000 ans, PhD thesis, Université Paris XI - Orsay, Paris, France.

Kühn, D., and T. Dahm (2008), Numerical modelling of dyke interaction and its influence on oceanic crust formation, Tectonophysics, 447, 53-65, doi:10.1016/j.tecto.2006.09.018.

Lacombe, O. (2012), Do fault slip data inversions actually yield "paleostresses" that can be compared with contemporary stresses? A critical discussion, C. R. Geosci., 344, 159-173, doi:10.1016/j.crte.2012.01.006.

Le Friant, A., E. Lebas, V. Clément, G. Boudon, C. Deplus, B. de Voogd, and P. Bachèlery (2011), A new model for the evolution of La Réunion volcanic complex from complete marine geophysical surveys, Geophys. Res. Lett., 38 L09312, doi:10.1029/2011GL047489.

Lehto, H. L., D. C. Roman, and S. C. Moran (2010), Temporal changes in stress preceding the 2004-2008 eruption of Mount St. Helens, Washington, J. Volcanol. Geotherm. Res., 198(1-2), 129-142, doi:10.1016/j.jvolgeores.2010.08.015.

Letourneur, L., A. Peltier, T. Staudacher, and A. Gudmundsson (2008), The effect of rock heterogeneities on dyke paths and asymmetric ground deformation: The example of Piton de la Fournaise (Réunion Island), J. Volcanol. Geotherm. Res., 173(3-4), 289-302, doi:10.1016/j. jvolgeores.2008.01.018.

López, D. L., and S. N. Williams (1993), Catastrophic volcanic collapse: Relation to hydrothermal processes, Science, 260(5115), $1794-1796$.

Maccaferri, F., M. Bonafede, and E. Rivalta (2011), A quantitative study of the mechanisms governing dike propagation, dike arrest and sill formation, J. Volcanol. Geotherm. Res., 208, 39-50, doi:10.1016/j.volgeores.2011.09.001.

MacDonald, G. A. (1972), Volcanoes, pp. 510, Englewood Cliffs, New Jersey, USA.

Maillot, E. (1999), Les systèmes intrusifs des volcans boucliers océaniques: lle de la Réunion (Océan Indien). Approche structurale et expérimentale, PhD thesis, Lab. Sc. Terre Univers Réunion, Université de la Réunion, France.

Malengreau, B., J.-F. Lénat, and J.-L. Froger (1999), Structure of Réunion Island (Indian Ocean) inferred from the interpretation of gravity anomalies, J. Volcanol. Geotherm. Res., 88, 131-146.

Marinoni, L. B., and A. Gudmundsson (2000), Dykes, faults and paleostresses in the Teno and Anaga massifs of Tenerife (Canary Islands), J. Volcanol. Geotherm. Res., 103, 83-103. 
Marinoni, L. B., and G. Pasquarè (1994), Tectonic evolution of the emergent part of a volcanic ocean island: Lanzarote, Canary Islands, Tectonophysics, 239(1-4), 111-137.

McDougall, I. (1971), The geochronology and evolution of the young volcanic island of Réunion, Indian Ocean, Geochim. Cosmochim. Acta, 85, 261-288.

McGuire, W. J. (1996), Volcano instability: A review of contemporary themes, Geol. Soc. London Spec. Pub., 110(1), 1-23.

Menand, T. (2008), The mechanics and dynamics of sills in layered elastic rocks and their implications for the growth of laccoliths and other igneous complexes, Earth Planet. Sci. Lett., 267(1-2), 93-99, doi:10.1016/j.epsl.2007.11.043.

Merle, O., and A. Borgia (1996), Scaled experiements of volcanic spreading, J. Geophys. Res., 101(B6), 13,805-13,817.

Michon, L., F. Saint-Ange, P. Bachelery, N. Villeneuve, and T. Staudacher (2007), Role of the structural inheritance of the oceanic lithosphere in the magmato-tectonic evolution of Piton de la Fournaise volcano (La Réunion Island), J. Geophys. Res., 112, B04205, doi:10.1029/ 2006JB004598.

Michon, L., V. Cayol, L. Letourneur, A. Peltier, N. Villeneuve, and T. Staudacher (2009), Edifice growth, deformation and rift zone development in basaltic setting: Insights from Piton de la Fournaise shield volcano (Réunion Island), J. Volcanol. Geotherm. Res., 184(1-2), 14-30, doi:10.1016/j.jvolgeores.2008.11.002.

Mitchell, N. C., D. G. Masson, A. B. Watts, M. J. R. Gee, and R. Urgeles (2002), The morphology of submarine flanks of volcanic ocean islands. A comparative study of the Canary and Hawaiian hotspot islands, J. Volcanol. Geotherm. Res., 115, 83-107.

Montgomery-Brown, E. K., D. K. Sinnett, K. M. Larson, M. P. Poland, P. Segall, and A. Miklius (2011), Spatiotemporal evolution of dike opening and decollement slip at Kỉlauea Volcano, Hawai'i, J. Geophys. Res., 116, B03401, doi:10.1029/2010JB007762.

Morgan, J. K., and P. J. McGovern (2005), Discrete element simulations of gravitational volcanic deformation: 1. Deformation structures and geometries, J. Geophys. Res., 110, B05402, doi:10.1029/2004JB003252.

Morgan, J. K., G. F. Moore, D. J. Hills, and S. Leslie (2000), Overthrusting and sediment accretion along Kilauea's mobile south flank, Hawaii: Evidence for volcanic spreading from marine seismic reflection data, Geology, 28(7), 667-670.

Morgan, J. K., G. F. Moore, and D. A. Clague (2003), Slope failure and volcanic spreading along the submarine south flank of Kilauea volcano, Hawaii, J. Geophys. Res., 108(B92415), doi:10.1029/2003JB002411.

Muller, J. R., G. Ito, and S. J. Martel (2001), Effects of volcano loading on dike propagation in an elastic half-space, J. Geophys. Res., 106, 101-113.

Oehler, J.-F. (2005), Les déstabilisations de flanc des volcans de l'île de La Réunion (Océan Indien): Mise en évidence, implcations et origines, PhD thesis, Lab. Magmas et Volcans, Université Blaise Pascal, Clermont-Ferrand, France.

Oehler, J.-F., P. Labazuy, and J.-F. Lénat (2004), Recurrence of major landslides during the last 2-Ma-history of Réunion Island, Bull. Volcanol., 66(7), 585-598, doi:10.1007/s00445-004-0341-2.

Oehler, J.-F., B. van Wyk de Vries, and P. Labazuy (2005), Landslides and spreading of oceanic hot-spot and arc shield volcanoes on Low Strength Layers (LSLs): An analogue modeling approach, J. Volcanol. Geotherm. Res., 144(1-4), 169-189, doi:10.1016/j. jvolgeores.2004.11.023.

Oehler, J.-F., J.-F. Lénat, and P. Labazuy (2007), Growth and collapse of the Réunion Island volcanoes, Bull. Volcanol., 70(6), 717-742, doi:10.1007/s00445-007-0163-0.

Owen, S., P. Segall, J. Freymueller, A. Miklius, R. P. Denlinger, T. Arnadottir, M. K. Sako, and R. Bürgmann (1995), Rapid deformation of the south flank of Kilauea Volcano, Hawaii, Science, 267(5202), 1328.

Owen, S., P. Segall, M. Lisowski, A. Miklius, R. P. Denlinger, and M. K. Sako (2000), Rapid deformation of Kilauea volcano: Global Positioning System measurements between 1990 and 1996, J. Geophys. Res., 105(B8), 18,983-18,998.

Parsons, T., and G. A. Thompson (1991), The role of magma overpressure in suppressing earthquakes and topography: Worldwide examples, Science, 253(5026), 1399-1402.

Parsons, T., N. H. Sleep, and G. A. Thompson (1992), Host rock rheology controls on emplacement of tabular intrusions: Implications for underplating of extending crust, Tectonics, 11(6), 1348-1356.

Peltier, A. (2007), Suivi, modélisation et évolution des processus d'injections magmatiques au Piton de la Fournaise (Réunion) à partir d'une analyse croisée de données de déformation, géochimiques et structurales, PhD thesis, Lab. GéoSc. Réunion - OVPF, Université de la Réunion, France.

Peltier, A., V. Ferrazzini, T. Staudacher, and P. Bachèlery (2005), Imaging the dynamics of dyke propagation prior to the 2000-2003 flank eruptions at Piton de La Fournaise, Reunion Island, Geophys. Res. Lett., 32, L22302, doi:10.1029/2005GL023720.

Peltier, A., T. Staudacher, and P. Bachèlery (2007), Constraints on magma transfers and structures involved in the 2003 activity at Piton de la Fournaise from displacement data, J. Geophys. Res., 112, B03207, doi:10.1029/2006JB004379.

Peltier, A., V. Famin, P. Bachèlery, V. Cayol, Y. Fukushima, and T. Staudacher (2008), Cyclic magma storages and transfers at Piton de La Fournaise volcano (La Réunion hotspot) inferred from deformation and geochemical data, Earth Planet. Sci. Lett., 270(3-4), 180-188, doi:10.1016/j.epsl.2008.02.042.

Pinel, V., and C. Jaupart (2004), Magma storage and horizontal dyke injection beneath a volcanic edifice, Earth Planet. Sci. Lett., 221(1-4), 245-262, doi:10.1016/s0012-821x(04)00076-7.

Pollard, D. D., and G. Holzhausen (1979), On the mechanical interaction between a fluid-filled fracture and the Earth's surface, Tectonophysics, 53, 27-57.

Pollard, D. D., and A. M. Johnson (1973), Mechanics of growth of some laccolithic intrusions in the Henry Moutains, Utah, II: Bending and failure of overburden layers and sill formation, Tectonophysics, 18(3-4), 311-354.

Pollard, D. D., and O. H. Muller (1976), The effect of gradients in regional stress and magma pressure on the form of sheet intrusions, J. Geophys. Res., 81, 975-984.

Pollard, D. D., P. T. Delaney, W. A. Duffield, E. T. Endo, and A. T. Okamura (1983), Surface deformation in volcanic rift zones, Tectonophysics, 94(1-4), 541-584.

Roman, D. C., S. C. Moran, J. A. Power, and K. V. Cashman (2004), Temporal and spatial variation of local stress fields before and after the 1992 eruptions of Crater Peak vent, Mount Spurr volcano, Alaska, Bull. Seism. Soc. Am., 94(6), 2366-2379.

Rubin, A. M. (1993), Tensile fracture of rock at high confining pressure: Implication for dike propagation, J. Geophys. Res., 98(B9), 15,919-15,935.

Rubin, A. M., and D. D. Pollard (1987), Origin of blade-like dikes in volcanic rift zones, USGS Prof. Pap., 1350(2), $1449-1470$.

Salvany, T., P. Lahitte, P. Nativel, and P.-Y. Gillot (2012), Geomorphic evolution of the Piton des Neiges volcano (Réunion Island, Indian Ocean): Competition between volcanic construction and erosion since 1.4 Ma, Geomorphology, 136(1), 132-147, doi:10.1016/j. geomorph.2011.06.009.

Schultz, R. A. (1995), Limits on strength and deformation properties of jointed basaltic rock masses, Rock Mech. and Rock Eng., 28(1), $1-15$. 
Sperner, B., and P. Zweigel (2010), A plea for more caution in fault-slip analysis, Tectonophysics, 482(1-4), 29-41, doi:10.1016/j. tecto.2009.07.019.

Sperner, B., B. Müller, O. Heidbach, D. Delvaux, J. Reinecker, and K. Fuchs (2003), Tectonic stress in the Earth's crust: Advances in the World Stress Map project, in New Insights Into Structural Interpretation and Modelling, vol. 212, Geological Society Special Publications, edited by D. A. Nieuwland, pp. 101-116, The Geological Society, London, U. K.

Staudigel, H., and H.-U. Schmincke (1984), The Pliocene Seamount series of La Palma/ Canary Islands, J. Geophys. Res., 89(B13), 11,195-11,215. Staudigel, H., G. Feraud, and G. Giannerini (1986), The history of intrusive activity on the island of La Palma (Canary Islands), J. Volcanol. Geotherm. Res., 27, 299-322, doi:10.1016/0377-0273(86)90018-1.

Swanson, D. A., W. A. Duffield, and R. S. Fiske (1976), Displacement of the south flank of Kilauea volcano: The result of forceful intrusion of magma into the rift zones, USGS Prof. Pap., 965.

Taisne, B., and C. Jaupart (2009), Dike propagation through layered rocks, J. Geophys. Res., 114, B09203, doi:10.1029/2008JB006228.

Tinard, P. (2007), Caractérisation et modélisation des déplacements du sol associés à l'activité volcanique du Piton de la Fournaise, île de La Réunion, à partir de données interférométriques. Août 2003-Avril 2007., PhD thesis, Lab. Magmas et Volcans, Université Blaise Pascal, Clermont-Ferrand, France.

Twiss, R. J., and J. R. Unruh (1998), Analysis of fault slip inversions: Do they constrain stress or strain rate?, J. Geophys. Res., 103(B6), $12,205-12,222$

Upton, B. G. J., and W. J. Wadsworth (1972), Peridotitic and gabbroic rocks associated with the Shield-forming lavas of Réunion, Contr. Mineral. and Petrol., 35, 139-158.

Vigneresse, J.-L., B. Tikoff, and L. Améligo (1999), Modification of the regional stress field by magma intrusion and formation of tabular granitic plutons, Tectonophysics, 302, 203-224.

Walker, G. P. L. (1990), Geology and volcanology of the Hawaiian islands, Pac. Sci., 44, 315-347.

Walker, G. P. L. (1999), Volcanic rift zones and their intrusion swarms, J. Volcanol. Geotherm. Res., 94, 21-34.

Wallace, R. E. (1951), Geometry of shearing stress and relation to faulting, J. Geol., 59(2), 118-130.

Walter, T. R. (2003), Buttressing and fractional spreading of Tenerife, an experimental approach on the formation of rift zones, Geophys. Res. Lett., 30(61296), doi:10.1029/2002GL016610.

Walter, T. R., V. Acocella, M. Neri, and F. Amelung (2005), Feedback processes between magmatic events and flank movement at Mount Etna (Italy) during the 2002-2003 eruption, J. Geophys. Res., 110, B10205, doi:10.1029/2005JB003688.

Watanabe, T., T. Masuyama, K. Nagaoka, and T. Tahara (2002), Analog experiments on magma-filled cracks: Competition between external stresses and internal pressure, Earth Planet Space, 54, 1247-1261.

van Wyk de Vries, B., and A. Borgia (1996), The role of basement in volcano deformation, Geol. Soc. London Spec. Pub., 110(1), 95-110.

van Wyk de Vries, B., and R. Matela (1998), Style of volcano-induced deformation: Numerical models of substratum flexure, spreading and extrusion, J. Volcanol. Geotherm. Res., 81, 1-18.

Zenzri, H., and L. M. Keer (2001), Mechanical analysis of the emplacement of laccoliths and lopoliths, J. Geophys. Res., 106, 13,781-13,792.

Zucca, J., D. Hill, and R. Kovach (1982), Crustal structure of Mauna Loa volcano, Haiwaii, from seismic refraction and gravity data, Bull. Seism. Soc. Am., 72, 1535-1550. 